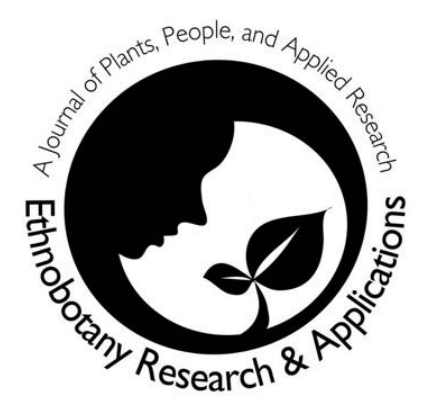

\title{
Ethnobotanical investigation of herbal food additives of Morocco used as natural dyes
}

\author{
Aziz Drioiche, Nadia Benhlima, Amale Kchibale, Salima \\ Boutahiri, Atika Ailli, Fatima El Hilali, Brahim Moukaid and \\ Touriya Zair
}

\section{Research}

\begin{abstract}
We undertook this ethnobotanical study for identifying and valorising medicinal plants exploited as food additives, and to establish a database of aromatic and medicinal plants used as food additives in traditional phytotherapy in Morocco (Fez-Meknes, Beni-Mellal, Khenifra, Draa-Tafilalt).
\end{abstract}

Methods: An ethnobotanical investigation was carried out among 200 main actors in traditional medicine (herbalists, healers, collectors, researchers) of Meknes, El Hajeb, Taza, Azrou, Ain Leuh, Boulemane, Ifrane, Khenifra, M'rirt, and Midelt; data on the use of plants as food additives and especially those used as tinctorial plants was collected via questionnaire sheets. The data was then subjected to principal component analysis.

Results: The population surveyed use plants for three major purposes: therapeutic $(39.60 \%)$, food $(35.84 \%)$ and cosmetics (24.56\%). Majority $(33.01 \%)$ of the people surveyed use plants to provide aroma, followed by dyes (25.24\%), spices (24.27\%) and as food preservative (17.48\%). We identified 56 plants used as dyes among the 79 species identified. From a botanical point of view, the 79 species listed are divided into 35 families. The most represented families are Asteraceae (16.55\%), Lamiaceae (15.17\%), Punicaceae (7.24\%) and Zingiberaccea $(7.24 \%)$. The survey confirmed the excessive use of Punica granatum L., Curcuma longa L., Matricaria camomilla L., Crocus sativus L. and Carthamus tinctorius L.

Conclusion: This study showed that the indigenous populations of the Pre-Rif, Middle Atlas and High Atlas regions use the plants as natural food additives, especially dyes. This wealth of plants is accompanied by knowledge and practices in phytotherapy acquired by the inhabitants over the centuries. We recommend that the documented plants be evaluated for their safety and efficiency in order to conclusively demonstrate their beneficial effects on health.

\section{Correspondence}

Aziz Drioiche ${ }^{1^{\star}}$, Nadia Benhlima ${ }^{1}$, Amale Kchibale $^{1}$, Salima Boutahiri ${ }^{1}$, Atika Ailli ${ }^{1}$, Fatima El Hilali ${ }^{1}$, Brahim Moukaid ${ }^{2}$ and Touriya Zair ${ }^{1}$ ${ }^{1}$ Research team of Chemistry Bioactive Molecules and the Environment, University Moulay Ismail of Meknes-Faculty of Sciences, BP 11201, Zitoune, Meknes-Morocco.

bSomafaco, Route d'El Jadida, Km 10,5 Lissasfa Casablanca - Maroc ${ }^{3}$ Department of Science Education Agriculture, Faculty of Education and Humanities, Gulu University, P.O. Box 166, Gulu

"Corresponding Author: Aziz Drioiche; a.drioiche@edu.umi.ac.ma / touria.zair@yahoo.fr

\section{Ethnobotany Research \& Applications}

21:11 (2021)

Key words: Ethnopharmacological survey, food additives, dyes, preservatives, plants, inventory, Punica granatum $\mathrm{L}$.

\section{Background}

Food additives represent a tiny part of our diet, are now at the centre of a wide debate that feeds ignorance, prejudice and concern. According to Decree 1795-14 of the Ministry of Agriculture and the Ministry of Health of Morocco, there are more than 250 authorized additives classified into 18 categories 
(Order of the Minister of Health Morocco 2014) compared to 507 in France where it is divided into 24 categories (Reynal et al. 2009). All additives (colourants, preservatives, antioxidants, stabilizers, gellings, thickeners, flavours, taste enhancers, sweeteners) are added to foods to facilitate their manufacture, preservation and also to improve their nutritional qualities (Chaudhary et al. 2010, Msagati et al. 2012, Abdulmumeen et al. 2012). With the proliferation of out-of-home meals, and the presence of synthetic food dyes in most industrial dishes, it has become impossible to abstain from them.

Synthetic dyes usually contain chemicals that in high doses, could cause bloating, nausea and vomiting (Selar 2017). In the interest of preventing such problems, a permissible daily dose, below which no effect is found in the organism, has been defined for some dyes, without raising the issue of the lack of information for consumers. Some synthetic dyes are also suspected carcinogens (Fiolet et al. 2018, Takkouche et al. 2005). In this scenario, the exploration natural plant resources to replace synthetic colouring is crucial. The pharmaceutical, cosmetics and food Industries look forward for the replacement of synthetic dyes with harmless biocolourants. Complex and multidisciplinary studies have shown the colouring properties of aromatic and medicinal plants (AMP) which are exploited as natural colourants (Kundal et al. 2016, Chengaiah et al. 2010). This diversity of the species (Table 1) has shown that the plant kingdom, especially aromatic and medicinal plants, is a repository of natural bioactive substances with potential to be used as food additives, especially as natural dyes with diverse therapeutic virtues.

In Morocco, dyeing plants (saffron, safflower, pomegranate and madder) are renowned for their tinctorial qualities (yellow and red sources) and their pharmacological and nutritional properties. Thus, many edible plants, used as food dyes (carrot, grape skin, onion peel, walnut scramble, etc) are, ancestral sources of pigments. However, we find that few scientific studies have been conducted on natural dyes derived from tinctorial plant extracts.

Currently, despite the progress of pharmacology, the therapeutic and food use of AMP is persistent in many countries, especially developing countries (Botineau 2012). Indeed, of the 500,000 species of plants on earth, at least 80,000 would have valuable medicinal properties (Anderson et al. 1982). Like other parts of the world, Morocco is a veritable reservoir of plant genetic resources, with about 4,500 species and subspecies of vascular plants (Dupont et al. 2015). Traditional medicine has always played an important role in Moroccan pharmacopeia. Also, traditional food know-how is now recognized as a heritage that must be conserved, valued and reinvented. Biodiversity, the quality and diversity of local know-how and products, as well as the beauty generations when the maximum number of informants know the species. The relative citation frequency (RFC) of species was calculated by of cultural landscapes, are undoubtedly among Morocco's strengths. Their appreciations is likely to restore economic and social dynamics and improved environmental sustainability in many rural areas. In this regard, the present study focuses on ancestral culinary and therapeutic knowledge in the pre-Rif, Atlas and top Atlas regions to establish a catalogue and inventory of AMP used as food additives (coloring, aroma and preservatives). The aim is to improve empirical knowledge through in-depth scientific research, focused on verifying the pharmacological and nutritional value of plants in the study areas. This would later help in the identification of new bioactive molecules of food and pharmaceutical interest.

\section{Methods}

\section{Study area}

The study area consists of 10 sites: Meknes, El Hajeb, Taza, Azrou, Ain Leuh, Boulemane, Ifrane, Khenifra, M'rirt, Midelt (Fig. 1). These sites can be grouped into three areas of the pre-rif mountains, the Middle Atlas and the High Atlas. These regions are reputed for traditional medicine.

\section{Sampling}

Ethnobotanical surveys were conducted between July 2017 and July 2018 to obtain a varied and comprehensive inventory. The sample consisting of herbalists, healers, collectors, researchers (pharmacists, doctors and academics) and associated actors was subdivided into ten strata, representing rural and urban municipalities. Using simple randomized sampling, 20 informants were then trained for each of the ten strata, and then are grouped to obtain a comprehensive sample of 200 informants.

A fact sheet in the form of a questionnaire (appendix 1) was designed to collect as much information as possible about the person surveyed (age, level of education, profession and family situation), data relating to AMP (areas of use; food uses as colourant, spices, preservatives, and flavourings; parts used and the adverse effects of these plants), and know-how concerning the therapeutic and food uses of natural colourants

\section{Data Analysis Using Ethnobotanical Indices}

\section{Relative Frequency of Citation (RFC)}

Relative frequency of citations reveals the local importance of each medicinal plant species used by peoples in the region. This index can also provide an indication of medicinal species are best known or have been used for a long time by the majority of informants and can be a source of reliability (Ouelbani et al. 2016). Knowledge about the medicinal uses of plants is easily preserved for future

dividing the citation frequency (CF) (the number of informants mentioning a useful species) by the total number of informants in the survey $(\mathrm{N})$. This RFC 
index ranges from 0 (when a species is not mentioned by any user as useful) to 1 (when all respondents mentioned the species as useful). RFC was calculated by using the formula RFC $=F C / N$ (Vitalini et al. 2013).

\section{Processing the results}

Data collected was treated and analysed by SPSS 22-32 software, then transformed into graphs or histograms with Microsoft Excel 2019. The statistical study was based on the Principal Component Analysis (PCA). This analysis is carried out using Pearson-type matrixes using the "PCA" function to establish, on the one hand, the correlation between the socio-demographic information collected regarding plants used as food additives in each study region, and on the other hand, between information about the use of plants in each study site. Intermediate correlation matrixes, correlation coefficients between variables and the two $\mathrm{F} 1$ and F2 axes, and the projection of variables in the F1 and F2 axis space were obtained through XLSTAT Software. The ethnobotanical RFC index has been calculated to select medicinal species with a high RFC, which will be evaluated in subsequent phytochemical and pharmacological work for the identification of important bioactive molecules.

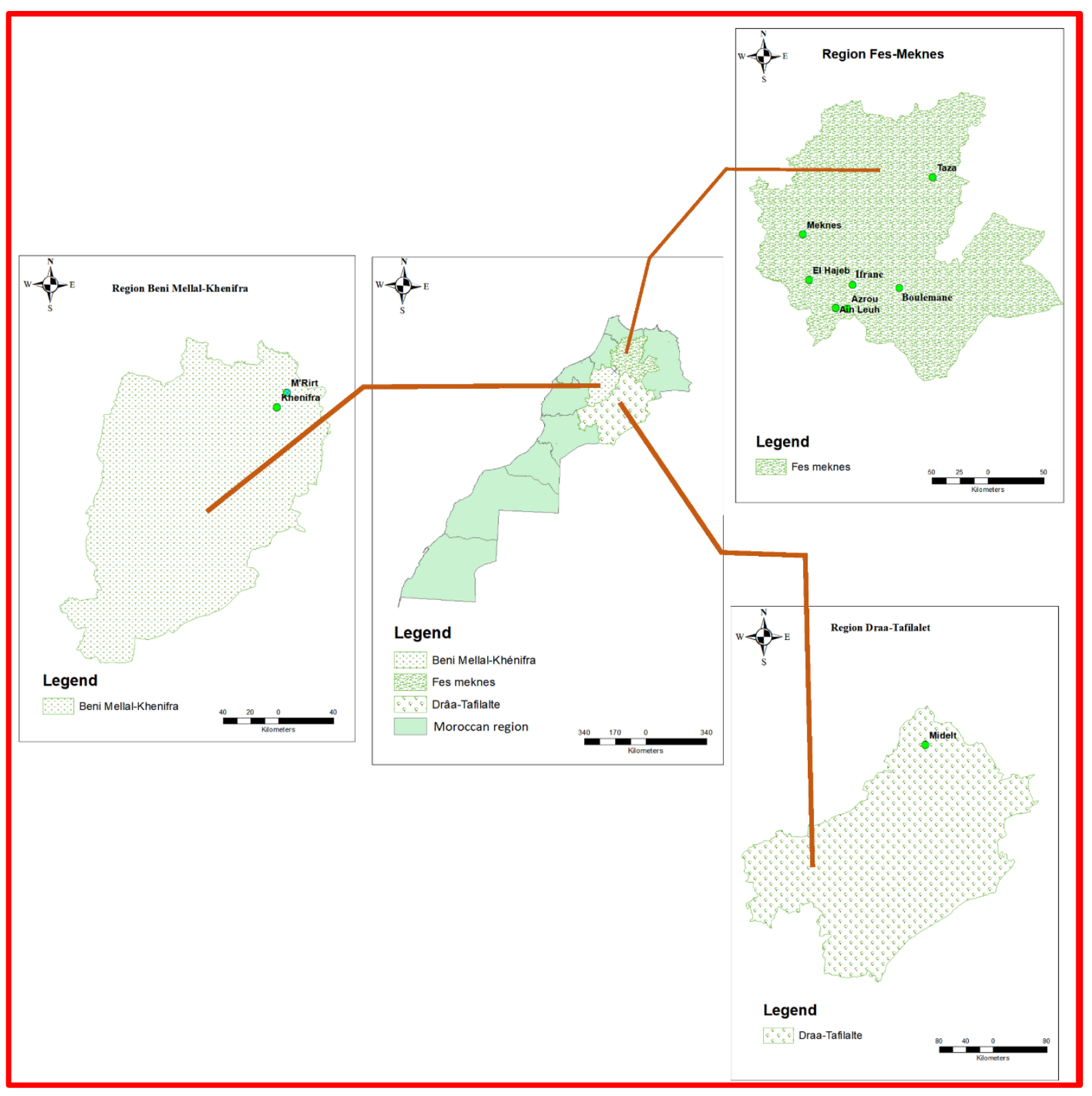

Fig. 1. Geographical location of the study area (Morocco) 


\section{Ethnobotany Research and Applications}

Table 1. Example dye plants and their medicinal properties

\begin{tabular}{|c|c|c|c|c|c|c|}
\hline Botanical family & Plant species & Used parts & Color & $\begin{array}{c}\text { Chemical composition : } \\
\text { pigment }\end{array}$ & Medical use & References \\
\hline Amaryllidaceae & Allium cepa L. & Onion bark & $\begin{array}{l}\text { Yellow, green, } \\
\text { orange }\end{array}$ & $\begin{array}{l}\text { Flavonoids, tannins and } \\
\text { anthocyanins }\end{array}$ & $\begin{array}{l}\text { Antimicrobials, antidiabetic, anti- } \\
\text { oxidants, digestive disorders, } \\
\text { urinary retention, aphrodisiac, } \\
\text { arteriosclerosis. }\end{array}$ & $\begin{array}{l}\text { (Dorsch 1997, } \\
\text { Hughes and Lawson } \\
\text { 1991. Prakash et al. } \\
\text { 2007) }\end{array}$ \\
\hline Anacardiaceae & Pistacia terebinthus L. & $\begin{array}{l}\text { Leaves and } \\
\text { galls }\end{array}$ & Yellow & $\begin{array}{l}\text { Anthocyanins, tannins: } \\
\text { Myrisitine; Gallotanique aci } \\
\text { d }\end{array}$ & $\begin{array}{l}\text { antiulcer, hepatoma, antimicrobial, } \\
\text { astringent, expectorant, healing, } \\
\text { antispasmodic }\end{array}$ & (Bozorgi et al. 2013) \\
\hline Asteraceae & Artemisia vulgaris $\mathrm{L}$. & Whole plant & Yellow & Flavonoids and tannins & $\begin{array}{l}\text { Tonic, antipyretic, antispasmodic, } \\
\text { vermifuge and stomach, hepatic, } \\
\text { dysmenorrhea, antimicrobial. }\end{array}$ & $\begin{array}{l}\text { (Abiri et al. 2018, } \\
\text { Gilani et al. 2005, } \\
\text { Khan and Gilani } \\
\text { 2009) }\end{array}$ \\
\hline Asteraceae & Calendula officinalis L. & flowers & Yellow to orange & $\begin{array}{l}\text { Flavonoids and } \\
\text { Carotenoids }\end{array}$ & $\begin{array}{lr}\text { Anti-inflammatory, } & \text { anti- } \\
\text { oedematous, antiviral, antitumor, } \\
\text { immunomodulatory, } \\
\text { dermatology. }\end{array}$ & $\begin{array}{l}\text { (Kalvachev et al. } \\
\text { 1997, Muley et al. } \\
\text { 2009, Zitterl-Eglseer } \\
\text { et al. 1997) }\end{array}$ \\
\hline Asteraceae & Carthamus tinctorius L. & flowers & red & $\begin{array}{l}\text { Quinochalcone NY2 } 75130 \\
\text { and 75135; NY27: } \\
\text { 75125; NR26: } 75140 \\
\text { carthamine }\end{array}$ & $\begin{array}{l}\text { Anti-inflammatory stabilizes blood } \\
\text { pressure, hepatic, removes bad } \\
\text { cholesterol, anti-cancer, } \\
\text { anticoagulant, antidiabetic. }\end{array}$ & $\begin{array}{l}\text { (Asgarpanah and } \\
\text { Kazemivash 2013) }\end{array}$ \\
\hline Asteraceae & Centaurea cyanus L. & flowers & Blue & Anthocyanins / Cyanidin & $\begin{array}{l}\text { Fever, menstrual disorders, } \\
\text { constipation, hepatoprotective, eye } \\
\text { irritation, anti-inflammatory, } \\
\text { immunomodulatory, } \\
\text { gastroprotective. }\end{array}$ & $\begin{array}{l}\text { (Garbacki et al. 1999, } \\
\text { Pirvu et al. 2012). }\end{array}$ \\
\hline Asteraceae & Cichorium intybus L. & $\begin{array}{l}\text { The whole } \\
\text { plant, flowers }\end{array}$ & Brown, blue & anthocyanins & $\begin{array}{l}\text { Diarrhea, strengthening of the } \\
\text { prostate and other reproductive } \\
\text { organs, lung cancer, hangover, and } \\
\text { bile duct purification, spasmolytic, } \\
\text { cholesterol, antiseptic, diabetes, } \\
\text { hepatoprotective }\end{array}$ & (Al-Snafi 2016) \\
\hline Asteraceae & Erigeron canadensis L. & flowers & Yellow & Flavonoids and Tannins & $\begin{array}{lcr}\begin{array}{l}\text { Antirheumatic, } \\
\text { diarrheal, }\end{array} & \text { diuretic, } & \text { anti- } \\
\text { inflammatory, } & \text { healing, } & \text { anti- } \\
\text { diabetes. } & \text { hemorrhoids, }\end{array}$ & $\begin{array}{l}\text { (Aslam et al. 2018, } \\
\text { Lateef et al. 2018). }\end{array}$ \\
\hline Brassicaceae & Isatis tinctoria $\mathrm{L}$. & leaves & Blue & Indigo & $\begin{array}{l}\text { Treat edema, tumors, wounds, } \\
\text { healing, ulcers, scurvy, antipyretic, } \\
\text { anti-inflammatory, antiseptic, anti- } \\
\text { inflammatory }\end{array}$ & $\begin{array}{l}\text { (Adachi et al. 2018, } \\
\text { Jung et al. 2018). }\end{array}$ \\
\hline
\end{tabular}


Ethnobotany Research and Applications

\begin{tabular}{|c|c|c|c|c|c|c|}
\hline Cesalpiniaceae & $\begin{array}{l}\text { Caesalpinia spinosa (Molina) } \\
\text { Kuntze }\end{array}$ & Cloves & Black & Hydrolyzable tannins & $\begin{array}{l}\text { Antimicrobial, spasmodic, anti- } \\
\text { cancer. }\end{array}$ & $\begin{array}{l}\text { (Kondo et al. 2006, } \\
\text { Skowyra et al. 2014. } \\
\text { Urueña et al. 2013). }\end{array}$ \\
\hline Euphorbiaceae & Chrozophora tinctoria L. & leaves & Green, Blue, Purple & Flavonoids anthraquinone & $\begin{array}{l}\text { Antimicrobial, dysentery, } \\
\text { antimutagenic, syphilis, typhoid, } \\
\text { diabetes, parasite }\end{array}$ & $\begin{array}{l}\text { (Abdalbasit 2004, } \\
\text { Maurya et al. 2016). }\end{array}$ \\
\hline Fabaceae & Acacia dealbata L. & Bark & Red to brown & $\begin{array}{l}\text { Tannins / } \\
\text { proanthocyanidins }\end{array}$ & Antimicrobial, antioxidant & (Silva et al. 2016). \\
\hline Fabaceae & $\begin{array}{l}\text { Acacia decurrens } \\
\text { (J.C.Wendl.) Willd. }\end{array}$ & Bark & Brown & $\begin{array}{l}\text { Tannins / } \\
\text { proanthocyanidins }\end{array}$ & $\begin{array}{l}\text { Headache, diarrhea, dysentery, } \\
\text { antiseptic, diabetes }\end{array}$ & (Subhan et al. 2018) \\
\hline Fagaceae & Quercus cerris L. & Bark & $\begin{array}{l}\text { Beige brown-gray to } \\
\text { black }\end{array}$ & Tannins & $\begin{array}{l}\text { Astringent, vasoconstrictor, anti- } \\
\text { inflammatory, antidiarrheal, } \\
\text { antiseptic, stomach. }\end{array}$ & $\begin{array}{l}\text { (Amorini et al. 1996; } \\
\text { Majer, 1984, Matić, } \\
\text { 2000) }\end{array}$ \\
\hline Iridaceae & Crocus sativus L. & Stigmas & Yellow & Carotenoids, crocetin. & $\begin{array}{lr}\begin{array}{l}\text { Neuroprotective, } \\
\text { hypolipidemic }\end{array} & \text { antitussive, } \\
\text { anticonvulsant, } & \text { antivity, } \\
\text { antidepressant, } & \text { anxiolytic, } \\
\text { cardiovascular } & \text { protection, } \\
\text { anticancer, antioxidant } & \\
\end{array}$ & (Hosseini et al. 2018) \\
\hline Boraginaceae & Origanum vulgare L. & leaves & Red-purple & Anthraquinone & $\begin{array}{l}\text { Antiseptic, } \\
\text { hypoglycemic, antispasmodic, } \\
\text { analgesic, } \\
\text { antioxidant }\end{array}$ & $\begin{array}{l}\text { (Lemhadri et al. } \\
\text { 2004, Mockute et al. } \\
\text { 2001) }\end{array}$ \\
\hline Lythraceae & Lawsonia inermis $\mathrm{L}$. & leaves & $\begin{array}{l}\text { Yellow to brown, } \\
\text { red, orange }\end{array}$ & Naphthoquinone, lawsone & $\begin{array}{l}\text { Antimicrobial, antispasmodic, anti- } \\
\text { parasitic, nephrolithiasis, } \\
\text { antidiarrheal, anti-inflammatory, } \\
\text { analgesic, antipyretic }\end{array}$ & $\begin{array}{l}\text { (Alia et al. } 1995 . \\
\text { Singh et al. 2015) }\end{array}$ \\
\hline Malvaceae & Hibiscus sabdariffa L. & $\begin{array}{l}\text { Red chalices, } \\
\text { fresh or dried }\end{array}$ & red & Flavonoids, anthocyanins & $\begin{array}{l}\text { Hypotensive, hepatoprotective, } \\
\text { anti-inflammatory, soothing, anti- } \\
\text { asthenic, antispasmodic, anti- } \\
\text { microbial }\end{array}$ & $\begin{array}{l}\text { (Riaz and Chopra, } \\
\text { 2018, Seung et al. } \\
\text { 2018, Su et al. 2018). }\end{array}$ \\
\hline Moraceae & Ficus carica L. & leaves & Yellow & $\begin{array}{l}\text { Flavonols, anthocyanins, } \\
\text { quercetin }\end{array}$ & $\begin{array}{l}\text { Anticancer, anemia, antioxidant, } \\
\text { coloring agent, antimalarial, } \\
\text { antiprotozoal, chemoprevention, } \\
\begin{array}{l}\text { anti-inflammatory, hemoptysis, } \\
\text { antiseptic. }\end{array}\end{array}$ & $\begin{array}{l}\text { (Badgujar et al. } 2014 . \\
\text { Gilani et al. 2008) }\end{array}$ \\
\hline Myrtaceae & Eucalyptus sp. & leaves & Yellow to brown & Quercetin & $\begin{array}{l}\text { Balsamic, thinner, anti-infective, } \\
\text { antiseptic, antirheumatic, stimulant, } \\
\text { tonic, antispasmodic }\end{array}$ & $\begin{array}{l}\text { (Hmiri et al. 2011; } \\
\text { Whitman and } \\
\text { Ghazizadeh 1994) }\end{array}$ \\
\hline Papaveraceae & Papaver rhoeas L. & flowers & Red, pink, purple & $\begin{array}{l}\text { Anthocyanins and } \\
\text { flavonoids }\end{array}$ & $\begin{array}{l}\text { Antitussive, an antiseptic, a } \\
\text { thickener, respiratory diseases, } \\
\text { antispasmodic, jaundice, ulcer. }\end{array}$ & $\begin{array}{l}\text { (Gürbüz et al. } 2003 . \\
\text { Soulimani et al. 2001) }\end{array}$ \\
\hline
\end{tabular}


Ethnobotany Research and Applications

\begin{tabular}{|c|c|c|c|c|c|c|}
\hline Punicaceae & Punica granatum L. & Bark and fruits & Yellow & Ellagitannins & $\begin{array}{l}\text { Antioxidants, hepatic, antidiarrheal, } \\
\text { deworming, anti-cancer, anti- } \\
\text { inflammatory, anti-diabetic }\end{array}$ & $\begin{array}{l}\text { (Arun and Singh } \\
2012 \text {, Lansky and } \\
\text { Newman 2007) }\end{array}$ \\
\hline Rosaceae & Alchemilla vulgaris $\mathrm{L}$. & Whole plant & Light orange & Tannins & $\begin{array}{l}\text { Antidiarrheal, diuretic, tonic, } \\
\text { vulnerary, hemostatic, sedative, } \\
\text { antirheumatic }\end{array}$ & $\begin{array}{l}\text { (Dzabijeva et al. } \\
\text { 2018, Lordani et al. } \\
\text { 2018). }\end{array}$ \\
\hline Rubiaceae & Galium verum $\mathrm{L}$. & $\begin{array}{l}\text { Roots and } \\
\text { rhizomes and } \\
\text { flowering tops }\end{array}$ & Red, pink & Anthraquinone & $\begin{array}{l}\text { Antispasmodic, astringent, diuretic, } \\
\text { vulnerary }\end{array}$ & $\begin{array}{l}\text { (Bradic et al. 2018, } \\
\text { Shafaghat et al. } \\
\text { 2010) }\end{array}$ \\
\hline Rubiaceae & Rubia tinctorum L. & Rhizomes & Red to orange & $\begin{array}{l}\text { Anthraquinone : Alizarin } \\
\text { and Purpurin }\end{array}$ & $\begin{array}{l}\text { Laxative, } \\
\text { diuretic, antilithiasis urinary, anti- } \\
\text { inflammatory, antioxidative, } \\
\text { antiproliferative, }\end{array}$ & $\begin{array}{l}\text { (Goktas et al. } 2009 \text {; } \\
\text { Mishchenko et al. } \\
\text { 2007) }\end{array}$ \\
\hline Thymelaeaceae & Daphne gnidium L. & Airborne & Yellow & $\begin{array}{l}\text { Flavones / Luteolin, } \\
\text { Apigenin ... }\end{array}$ & $\begin{array}{l}\text { Antiseptics, depurative, healing, } \\
\text { insecticide. }\end{array}$ & $\begin{array}{l}\text { (Cottigli et al. 2001; } \\
\text { Cottiglia et al. 2002) }\end{array}$ \\
\hline Urticaceae & Urtica dioica L. & Whole plant & Yellow & Flavonoids & $\begin{array}{l}\text { Tonic, astringent, vasoconstrictor, } \\
\text { hemostatic, anti-anemic, rickets, } \\
\text { depurative, anti-infectious, anti- } \\
\text { rheumatic, diuretic, uric acid } \\
\text { suppressor, hepatic drainage, } \\
\text { antidiarrheal, } \\
\text { lactogenic, revulsive stomachic, }\end{array}$ & $\begin{array}{l}\text { (Asgarpanah and } \\
\text { Mohajerani 2012, } \\
\text { Testai et al. 2002) }\end{array}$ \\
\hline Zingiberaceae & Curcuma longa L. & $\begin{array}{l}\text { Root or } \\
\text { rhizome }\end{array}$ & Yellow-orange & Curcumin & $\begin{array}{lcr}\text { Antioxidant, } & \text { bloating } & \text { anti- } \\
\text { inflammatory, } & \text { renal, intestinal, } \\
\text { anticancer } & \text { drugs, vasodilator, } \\
\text { spasmodic, } & \text { inotropic } & \text { and } \\
\text { chronotropic } & & \end{array}$ & $\begin{array}{l}\text { (Ashraf, 2018, Jamil } \\
\text { et al. 2018). }\end{array}$ \\
\hline Zygophyllaceae & Peganum harmala L. & Seed & Red rose & Anthraquinone & $\begin{array}{l}\text { Antibacterial, antifungal, antiviral, } \\
\text { antioxidant, anti-diabetic, anti- } \\
\text { tumor, anti-inflammatory, cytotoxic } \\
\text { and insecticidal as well as } \\
\text { hepatoprotective } \\
\text { antinociceptive effects }\end{array}$ & $\begin{array}{l}\text { (Asgarpanah and } \\
\text { Ramezanloo 2012) }\end{array}$ \\
\hline
\end{tabular}




\section{Results and discussions}

\section{Use of plants by gender}

Our study finds that men and women practice traditional medicine; mong the population who practice traditional medicine, $61.62 \%$ are men and $38.38 \%$ are women (Fig. 2). This reflects men specialise more on traditional medicine compared to women. The difference in the percentages observed is explained on the one hand by the number of men interviewed compared to women, and on the other hand, men are more active in the field of AMP than women (herbalists, collectors, etc.). However, in recent years, the participation of women has been increasingly noticed through the creation of associations, cooperatives or even pharmacies specializing in medicinal plants (Benkhnigue et al. 2016, Hmamouchi 2001). Hence, the share of women practitioners is bound to increase over time.

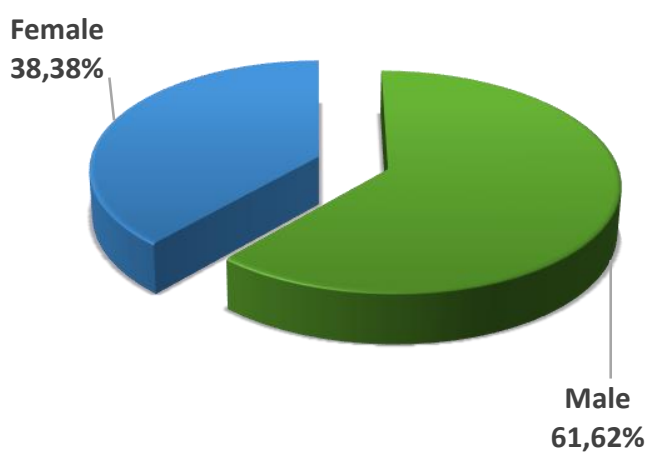

Fig. 2. Distribution of plant use by gender

\section{Use of plants by age}

Age plays a very important role in the activity of traditional medicine, the treatment of survey results has provided the graph below: Figure 3, which clearly shows the distribution of age percentages in study areas.

The use of aromatic and medicinal plants as natural food additives (dyes, preservatives, aroma and dietary supplements) in the study areas, is generally inherited from the previous generation. Though traditional use is widespread in all age groups, people over the age of 40 years have a high frequency of use of medicinal plants of $34.34 \%$. These results are in line with other ethnobotanical work carried out at the national level, such as the work of Benlamdini in the forest of the Eastern High Atlas (High Moulouya) (Benlamdini et al. 2014) which showed that the elderly have more experience and knowledge related to aromatic and medicinal plants compared to other age groups. Our study also shows that young people have little interest in the therapeutic use of plants and do not believe in traditional medicine, preferring instead modern medicine. This result is similar to those obtained in previous ethnobotanical studies conducted in other regions of Morocco (Eddouks et al. 2017; Mehdioui and Kahouadji 2007). This reflects that the transmission of traditional knowledge from the elderly to the young is on the decline, and require specific interventions. However, there is relatively lesser frequency of use in the age group of 50-59 years. This is because, people over fifty years of age represent a population that is less and less active, and the majority of which is at risk of developing diseases with high co-morbidity such as kidney failure, heart problems, diabetes, cancer, etc. These diseases frighten people and limit the use of plants, especially for a population with a modest level of education.

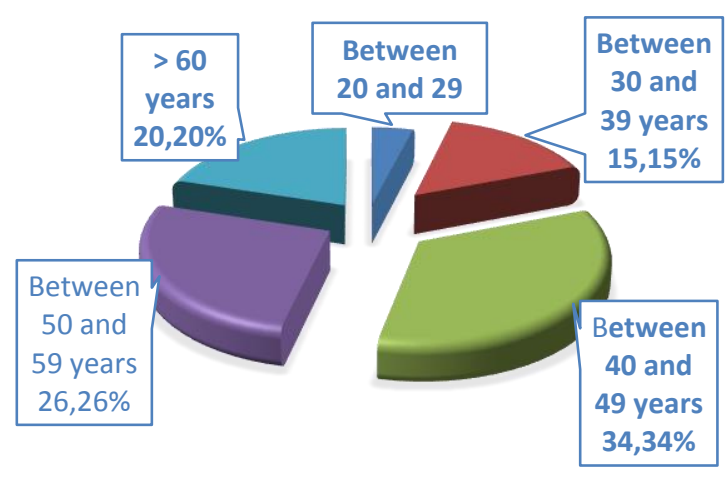

Fig. 3. Use of food additives by age group

\section{Use of aromatic and medicinal plants (AMP) according to the marital status}

The use of AMP is more in married persons (87.88\%) than in singles $(10.10 \%)$, and divorcees $(2.02 \%)$ (Fig. 4). The married perhaps due to their greater responsibility in the homes, know more on the therapeutic effects of plants, and are involved in preparing infusions or decoctions for the care of their family especially for their children. These results confirm those obtained by (Benkhnigue et al. 2010; El Amri et al. 2015) who showed that married couples are the depositories of the secrets of medicinal plants and the inheritance of family knowledge adapted to their family. We can deduce that the activities of this population related to the AMP field are sources of major revenue that provide for the purpose of their needs and to address the problems of precariousness in which it lives. On the social level, the aromatic and medicinal plants sector remains a very promising sector in terms of creating revenue-generating activities through the development of natural plant resources in the commercial and pharmacological aspects. This is proven by several ethnobotanical surveys such as the work of El Azzouzi (Elazzouzi et al. 2018) in the same study region. 


\section{Occupation}

Our study focused mainly on people who routinely exploit plants in various fields such as herbalists, healers, pickers, etc. to be able to extract more accurate information about AMP exploited as food plants and condiments (food additives). Users with information on food additives based on medicinal plants (Fig. 5) are herbalists with a percentage of $44.44 \%$, collectors $13.13 \%$, farmers $9.09 \%$, Operators $6.06 \%$, researchers $2.02 \%$, healers $2.02 \%$, and others (housewives, pharmacists, etc) with a frequency of $23.23 \%$. According to a study carried out in 15 Moroccan cities among 2000 people, drug dealers were ranked first in the exploitation of aromatic and medicinal plants and constituted $(98.4 \%)$, followed by herbalists $(17.7 \%)$, pharmacists $(8.1 \%)$ and finally healers $(5.8 \%)$ (Errajraji et al. 2010).

\section{Use of AMP according to education level}

In our study area, $37.63 \%$ of the population are formally illiterate. This relatively high percentage is directly correlated with the level of education of the local population. While the levels of education (primary and secondary) represent $33.33 \%$ and $17.20 \%$ respectively. In contrast, university students and researchers use aromatic and medicinal plants very little, at the rate of $11.83 \%$ (Fig. 6). These results are similar to the work of Bammu (2015) in the Meknes-Tafilalt region (Bammou et al. 2015). Also, other studies have shown that the know-how on the use of medicinal plants is generally held by people not educated through the formal sector (Lahsissene et al. 2009, Omer et al. 2012).

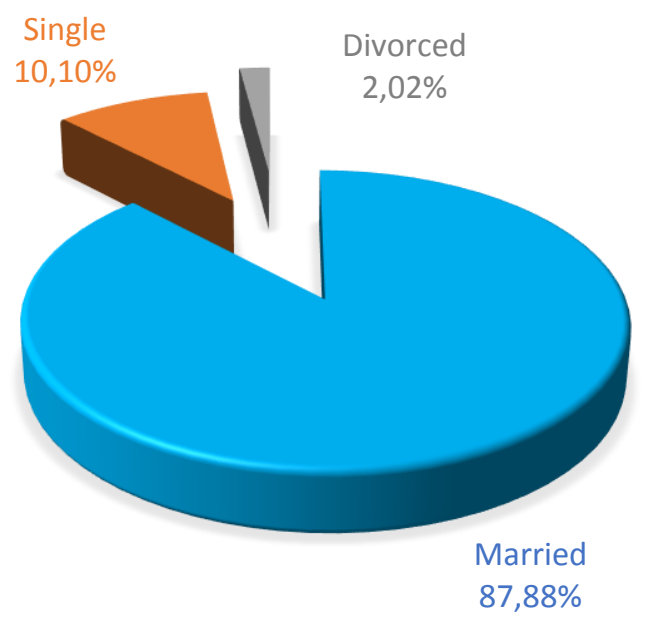

Fig. 4. Frequency of use of food additives according to marital status

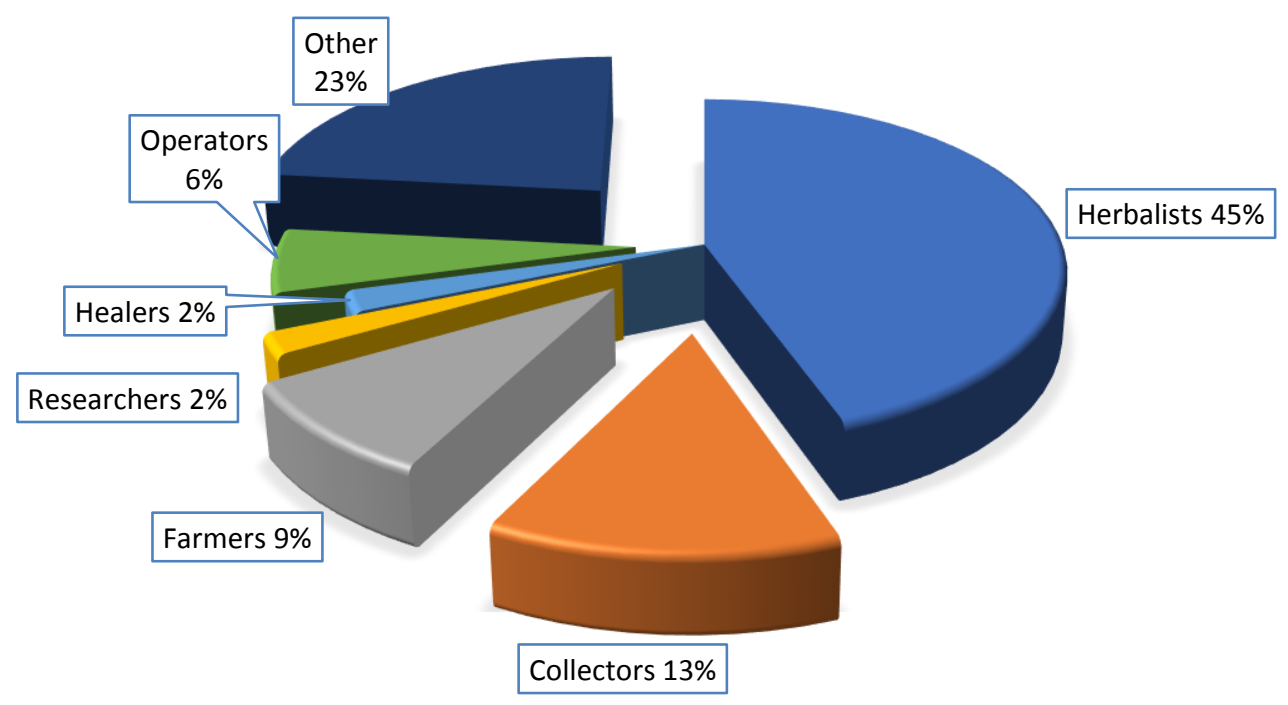

Fig. 5. Distribution of informants surveyed by occupation 


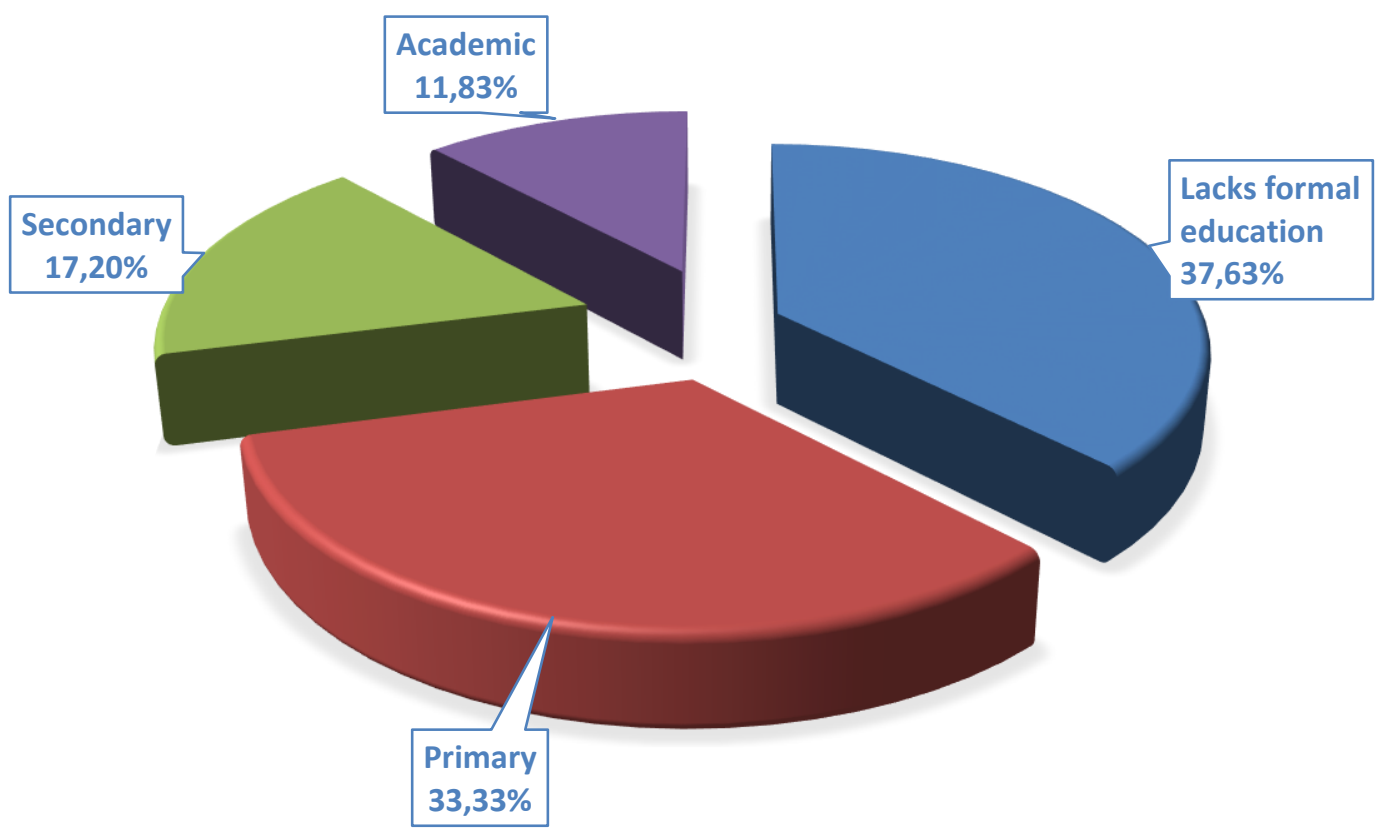

Fig. 6. Distribution of medicinal plant users by grade level

\section{Multivariate analysis of socio-demographic data on PCA informants}

Figure 7 shows the PCA based on all socio-demographic data of informants versus plants used as sources of natural food additives in each study region.

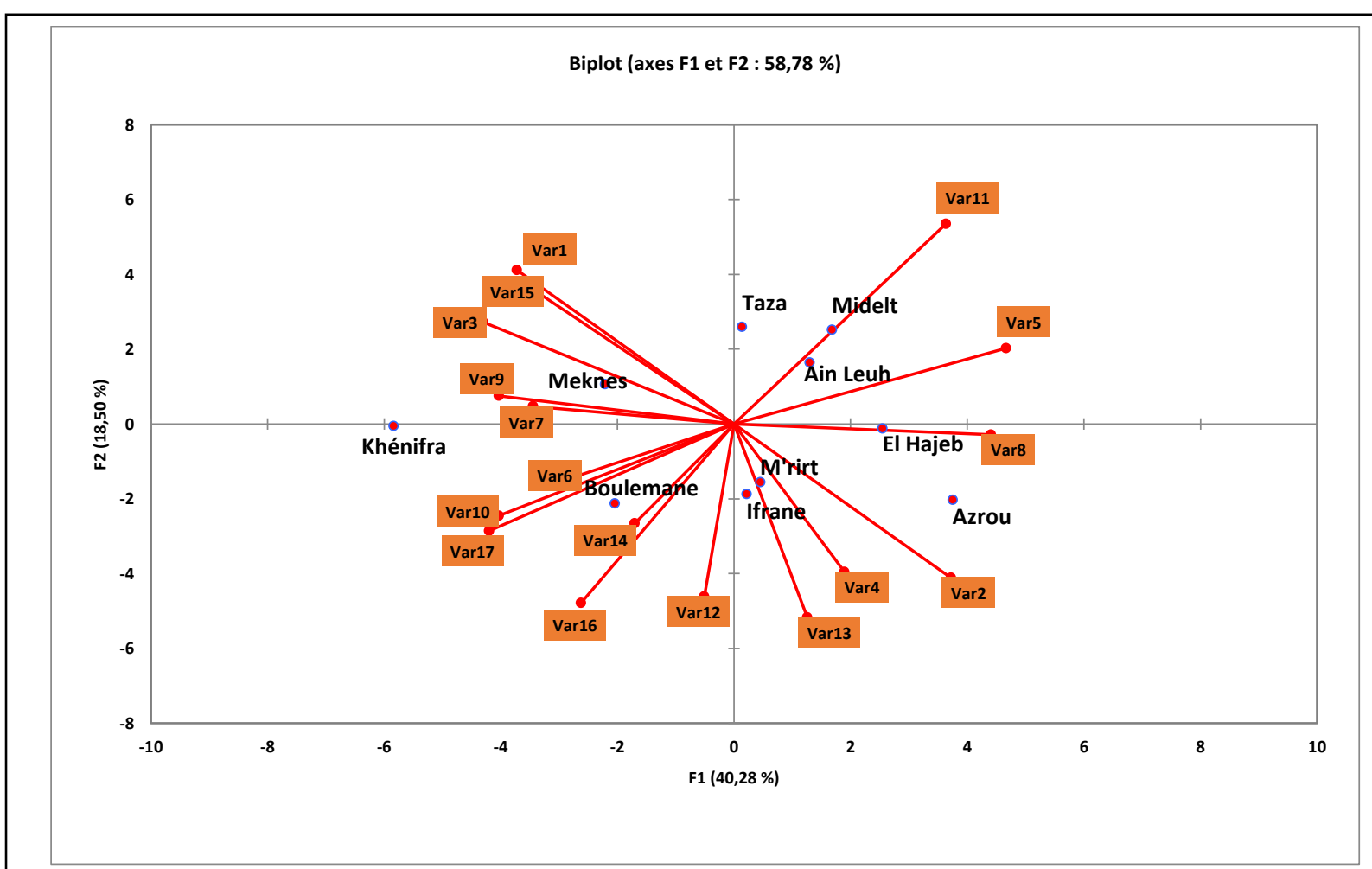

Fig. 7. Graphical Approach to Principal Component Analysis According to the Plan (F1xF2)

(Gender variables: var 1: Male, var 2: Female.Age groups variables: var 3: age range between 20 and 29 years old, var 4: between 30 and 39 years old, var 5: between 40 and 49 years old, var 6: between 50 and 60 years of age, var 7: age at over 60. Family situation variables: var 8: married, var 9: single, var 10: divorced. Profession variables: var 11: herbalists, var12: collectors, var13: farmers, var14: researchers, var15: healers, var16: farmers, var17: other professions.) 
Examination of the correlation matrix between variables (Fig. 7) reveals the presence of sets of variables, made up of well-correlated variables. Variables 5 and 11 are positively correlated, i.e. herbalists over the age of 40 have more recourse to traditional medicine. The majority of the population surveyed in Taza, Midelt, El Hajeb and Azrou provinces are herbalists aged 40 to 49 , married and have more knowledge about the field of plants. Indeed, in the Moroccan society herbalists are considered as more reliable sources of information and as paramedics.

Variables $12,13,4$ and 2 are positively correlated in the same way. In this case, women from the M'rirt and Ifrane regions, whether pickers or farmers over the age of 30 , have more recourse to the use of natural food additives in daily life; this is explained by the socio-economic situation of Middle Atlas regions, which is mediocre, knowing that the primary financial resource of this population remains is agricultural incomes.

Variables 6, 10, 14, 16 and 17 are positively correlated. Farmers and researchers aged 50 years old in the Boulemane region have been identified as useful sources of information on aromatic and medicinal plants used as food additives. This region is characterized by the presence of a significant wealth of plants, and the presence of several cooperatives and associations that exploit the richness and natural biodiversity of the region at the national and international level.

Finally, in the Meknes region, young people between the ages of 20 and 29, as well as older healers, represent the target population, which has guaranteed ancestral know-how in the field of plants.

\section{Inventory of aromatic and medicinal plants listed as sources of food additives}

From the 200 records filled out by the inhabitants in the regions studied, we inventoried 79 species of medicinal plants (appendix 2 ), belonging to a total of 35 botanical families (appendix 3). The survey identified 56 plant species used as sources of natural dyes, followed by 36 species used as aromatic plants and 31 as sources of natural preservatives. The determination of the scientific nomenclature of the species was carried out at the laboratory of plant botany and ecology of the scientific institute of Rabat.

Among the 35 families identified, the ones mostly used are: Asteraceae with a frequency of use of $16.55 \%$ followed by Lamiaceae, Punicaceae and Zingiberaceae with frequencies of use of $15.17 \%$, $7.24 \%$ and $7.24 \%$ respectively. Other families account for fewer than $5.17 \%$. These botanical families are the most represented in Morocco according to the latest floristic reports of the scientific institute of Rabat, and the most scientifically studied (Zakariya et al. 2018, Salhi et al. 2019). These families are primarily an important source of essential oils, phenols and flavonoids (Bouyahya et al. 2018, Ait-Sidi-Brahim et al. 2019). The predominant species used was Punica granatum L. with a relative citation frequency of $0.11 \%$, followed by Curcuma longa L. and Matricaria camomilla L. with a frequency of $0.09 \%$, as well as Crocus sativus L. $(0.08 \%)$, Capsicum annuum L. and Carthamus tinctorius L. with a frequency of $0.05 \%$. Various studies on the rind of the pomegranate fruit have shown that it contains two important benzoic acids, gallic acid and ellagic acid. It also contains hydroxycinnamic acids, derived from flavone molecules responsible for the yellow color, and anthocyanidins, responsible for the red color of pomegranates. Many studies have revealed the presence of ellagitannins, such as punicalin, punicalagine, corilagine, granatine $A$ and granatine $B$ (Fennane 2004). These antioxidant tannins, which represent up to $28 \%$ of the fruit's skin (Fennane 1998), have the ability to combat the oxidation of lowdensity lipoproteins known by bad LDL cholesterol (Fennane 1999).

\section{The use of plant species}

Use of aromatic and medicinal plants

The entire population investigated uses aromatic and medicinal plants for various purposes, either for their well-being or for healing and feeding.

\section{Origin of the information}

Figure 8 presents the origin of the information concerning the use of AMP. Indeed $58,59 \%$ of the population use aromatic and medicinal plants based on the experiences of the others, $22 \%$ of the population refers to the herbalists, while $8,08 \%$ of the people consult books and articles. At least $5,05 \%$ of people prefer to see audiovisual media, while 3,03\% of the population surveyed refer to training, while, $2,02 \%$ of the population collect information from social networks. People use medicinal plants particularly based on the experiences of others, which shows that traditional practices are transmitted from people to people (Anyinam 1995).

\section{Areas of use}

Figure 9 presents the areas of use of aromatic and medicinal plants. From this figure, we find that AMP are heavily exploited in different areas. Indeed, the population surveyed uses plants in three specific areas: therapeutic, food and cosmetic in the following order, $39.60 \% ; 35.84 \%$ and $24.56 \%$. It should be noted that some species of aromatic and medicinal plants, such as thyme and chamomile, are highly appreciated and used by the population in all three fields. 


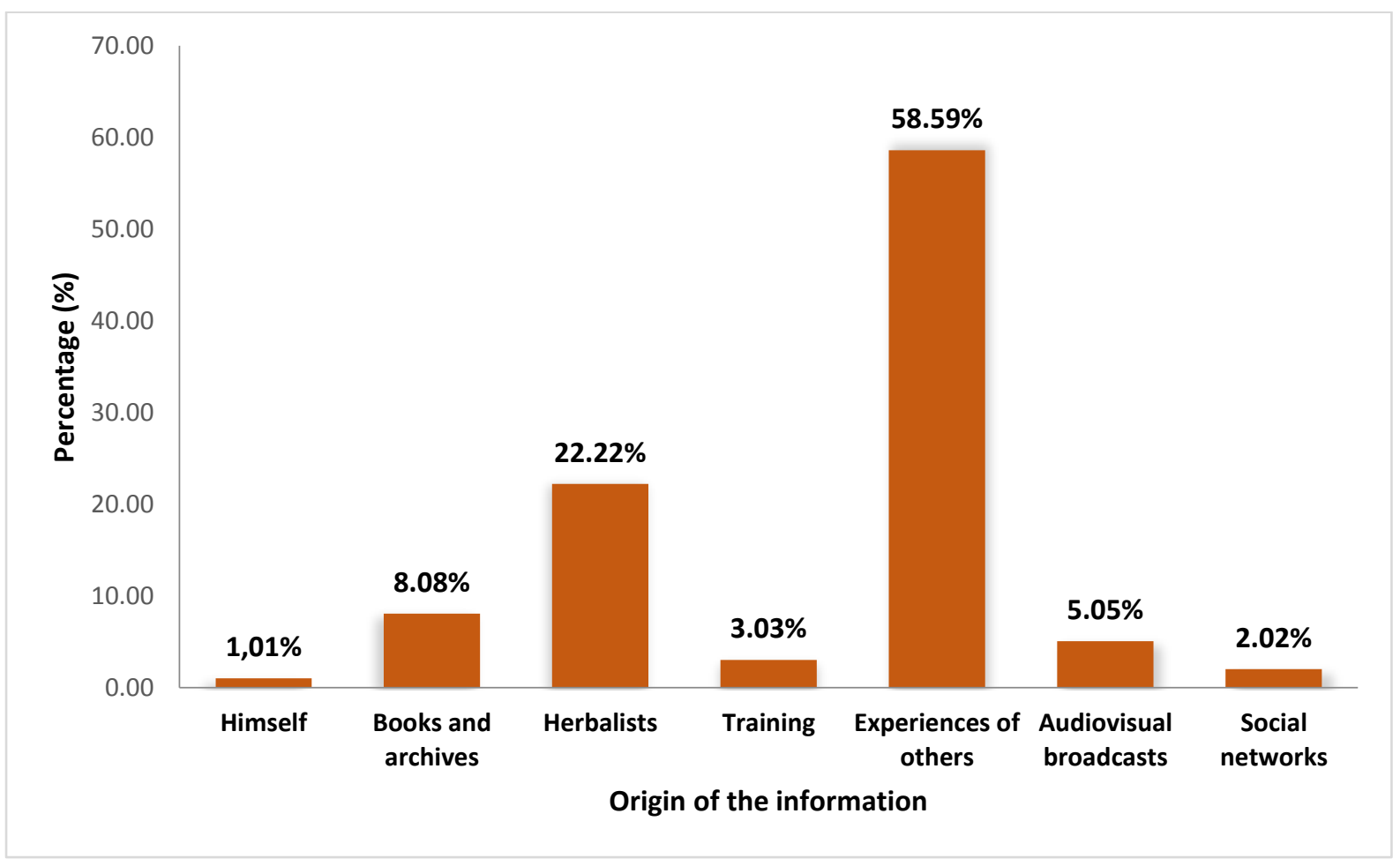

Fig. 8. Origin of the information related to the use of plants

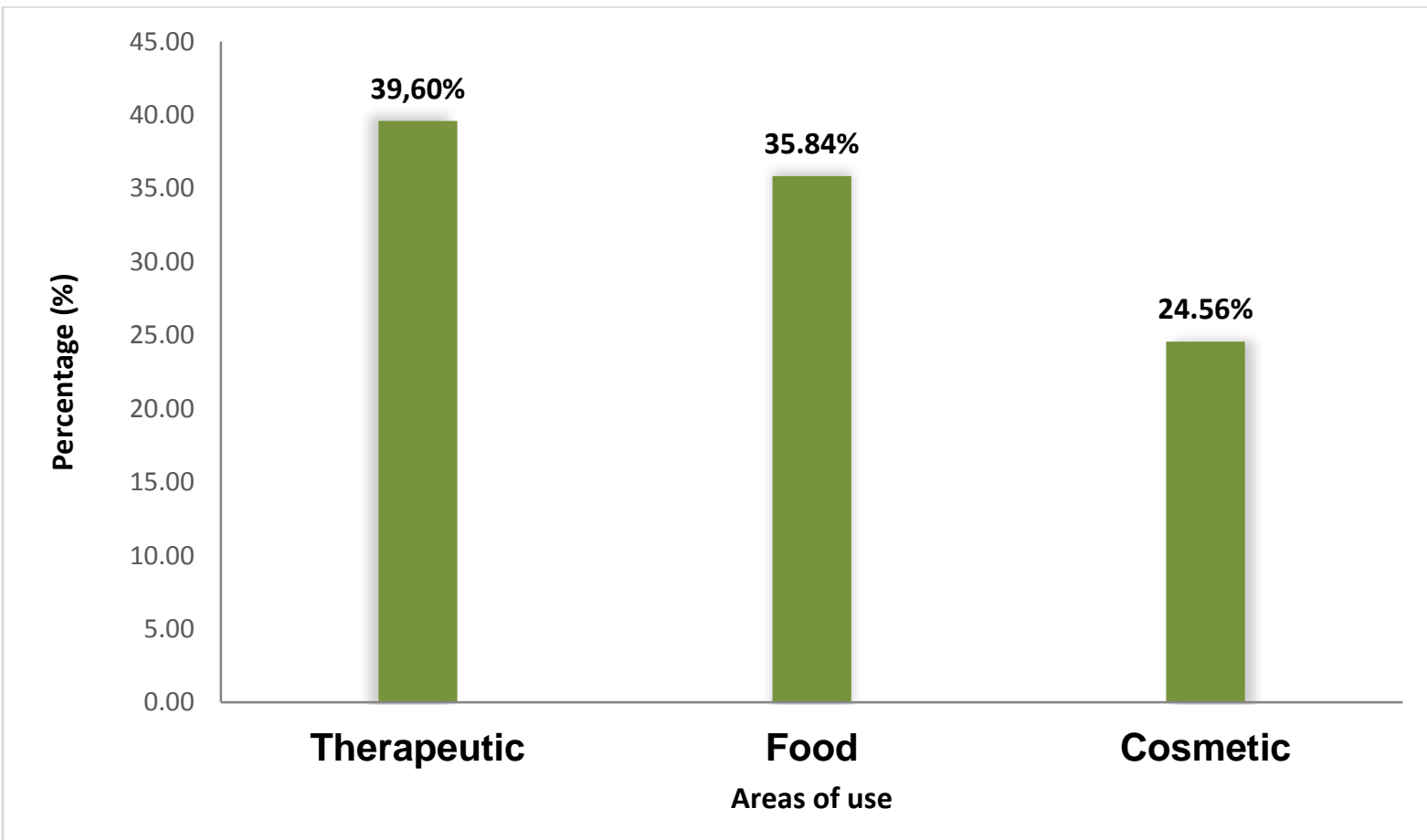

Fig. 9. Areas of use 


\section{Food use}

According to figure 9, a significant percentage $(35.84 \%)$ of the population surveyed uses aromatic and medicinal plants in the food field. Figure 10 specifies the food use of these plants as coloring, spice, preservative and aroma. In fact, $33.01 \%$ of people use plants as aromas to change the smell or taste of food, followed by $25.24 \%$ of respondents who use plants as dyes. So, on the one hand, $24.27 \%$ of the people surveyed use plants as a spice to give a savorto their food. On the other hand, $17.48 \%$ of the people surveyed use these plants as preservatives in order to prolong the duration of food. Thus, people use aromatic and medicinal plants with preservation properties.

Dyes are useful molecules in many applications; from food to textiles, cosmetics and coatings. Some molecules involved in the production, formulation or used as tinctorial materials are nevertheless pinned by national regulations (Morocco). In addition, according to this study, natural dyes are exploited primarily in three areas: food, cosmetics and textiles or weaving (Fig.11). In fact, $48.41 \%$ of the tinctorial plant's inventories are used to color foodstuffs, followed by $35.03 \%$ to color hair, and finally, they are used in the field of textile (weaving) to dye fabrics and yarns with $16.56 \%$.

\section{Use of plants as natural dyes}

Traditional applications of coloring plants differ from one country to another, and from one ethnic group to another. Some plants are traditionally used as dyes for culinary reasons, for aesthetic or intrinsic efficiency purposes. This knowledge and knowledge about the properties of these plants are acquired by ancestral heritage. Similarly, the investigations carried out have made it possible to understand and realize that the vast majority of rural populations use the same plants for therapeutic uses. Figure 12 illustrates the different areas of use of natural dyes. At least $36.71 \%$ of the colouring plants inventoried are used simultaneously in the three areas: therapeutic, food and cosmetics. And $29.11 \%$ are used in the therapeutic and food fields, while $6.33 \%$ are used just in the food. These results are in perfect correlation with other works. Nonetheless, tinctorial plants have rarely been studied in Africa. Some authors have cited them in ethnobotanical surveys for other uses, especially in traditional medicine (Raponda-Walker et al. 1961, Bouquet 1969, Jansen et al. 2005, Adjanohoun 1988, Kimpouni 2001, Motte 1980).

\section{Parts used}

Flowers are the most used plant part with a percentage of $36,13 \%$ (Fig. 13), followed by roots $(27,74 \%)$, fruits $(18,06 \%)$, bark $(6,45 \%)$, leaves $(5,81 \%)$, seeds $(3,87 \%)$ and finally the whole plant with a percentage of $1,94 \%$. The high frequency of flower use can be explained by the ease and speed of its harvest as well as the richness of its flowers in secondary metabolites, especially flavonoids that are known as sources of colors and other medicinal and aromatic properties.

\section{Adverse effects}

The list of AMP species collected shows plants whose adverse effects have been proven by several scientific studies (Mantle et al. 2001, Roach et al. 1987, Shanker et al. 2005, Jouad et al. 2001). At least $15,03 \%$ of the coloring plants inventoried have adverse effects compared to $84.97 \%$ (Fig. 14). Among these plants are Daphne gnidium L. and Ruta montana L. which are responsible for diarrhea, digestive spasms, as well as other digestive disorders such as vomiting and hypersalivation. Indeed, it should be noted that the majority of the population surveyed are unaware of the adverse effects on certain plants used and the modalities of their use, including the methods of preparation and the quantity used. In light of this study, we would like to raise awareness among the local population about the risks and dangers of the anarchic use of plants for food and plant therapeutics, in particular, the use of plants as additives. (Dyes, preservatives or aromas).

\section{Therapeutic properties of inventoried natural dyes}

The population uses aromatic and medicinal dyes for their therapeutic properties (Fig. 15). Thus, 38.56\% of respondents use these plants against other pathologies such as metabolic, dermatological, neurological diseases, followed by $37.91 \%$ of users who use these plants against infectious diseases caused by fungi and bacteria, while other users use these plants as antioxidants and anti-inflammatory drugs with a percentage of $17.65 \%$ and $5.88 \%$ respectively.

\section{The most common colours}

Among the commonly used and mostly wanted colours by the population surveyed (Fig. 16), yellow was preferred $(66.01 \%)$; compared to other colours; red colouring (16.99\%), orange colouring (9.15\%) and last, the Acajou, black and Brown coloration with percentages of $4.58 \%$, up to $1.96 \%$ and $1.31 \%$. most people use the yellow colour most often by mixing it with a primary dye to adjust the hue. In addition, the source of the yellow colour is the most universally widespread worldwide (Dikshit et al. 2018). Thus, the majority of plants identified in this survey are rich in phenolic compounds a source of yellow pigments, which are used as spice, colours, conservatives and aromas, especially from saffron, safflower and pomegranate tree. 


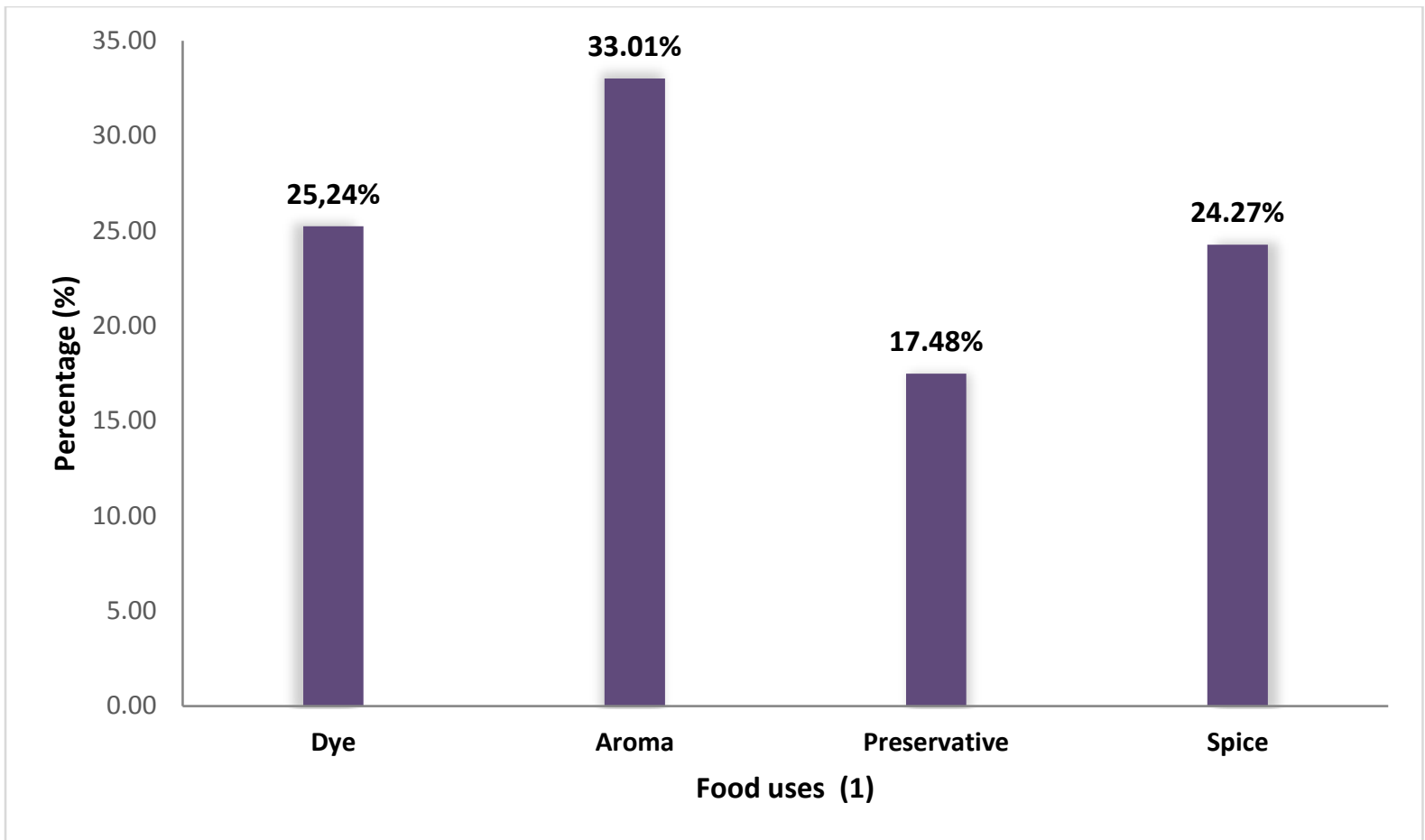

Fig. 10. Food uses of aromatic and medicinal plants

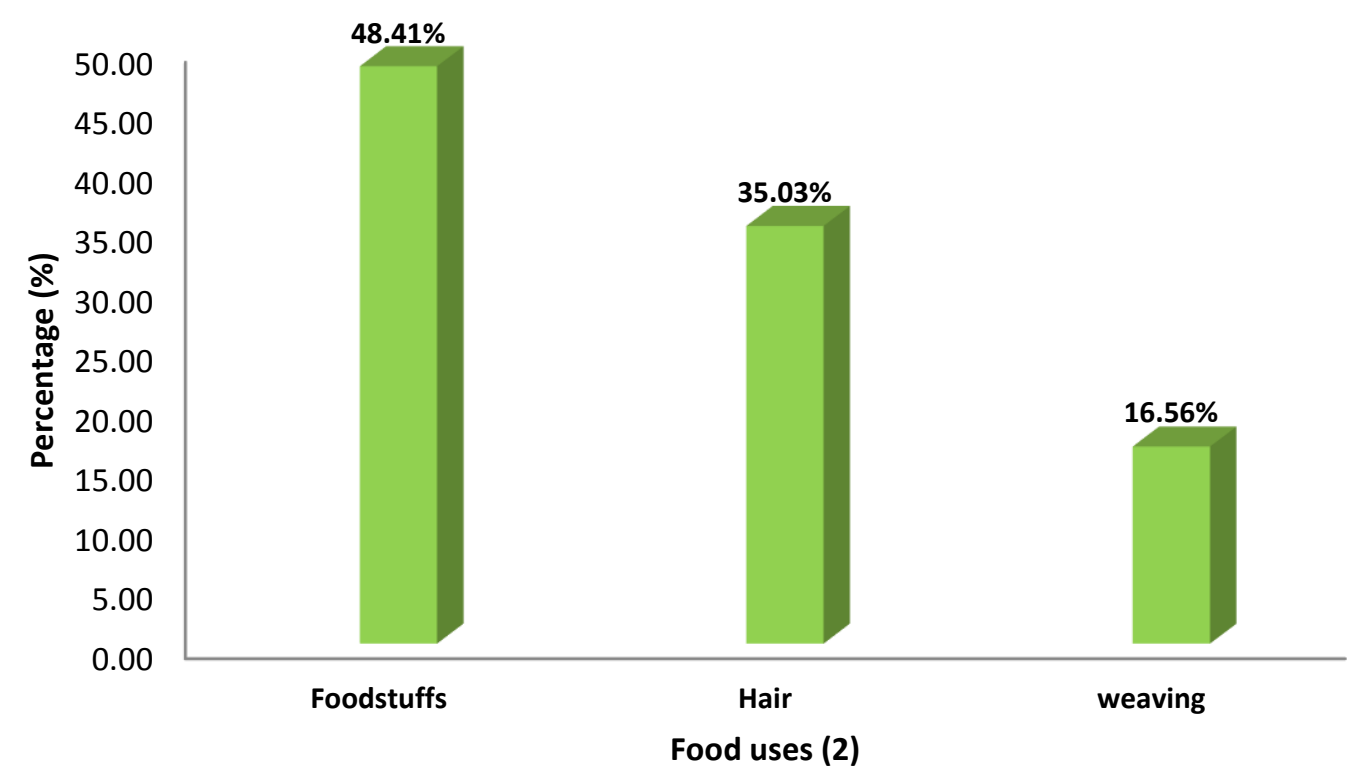

Fig. 11. Field of use of natural dyes 


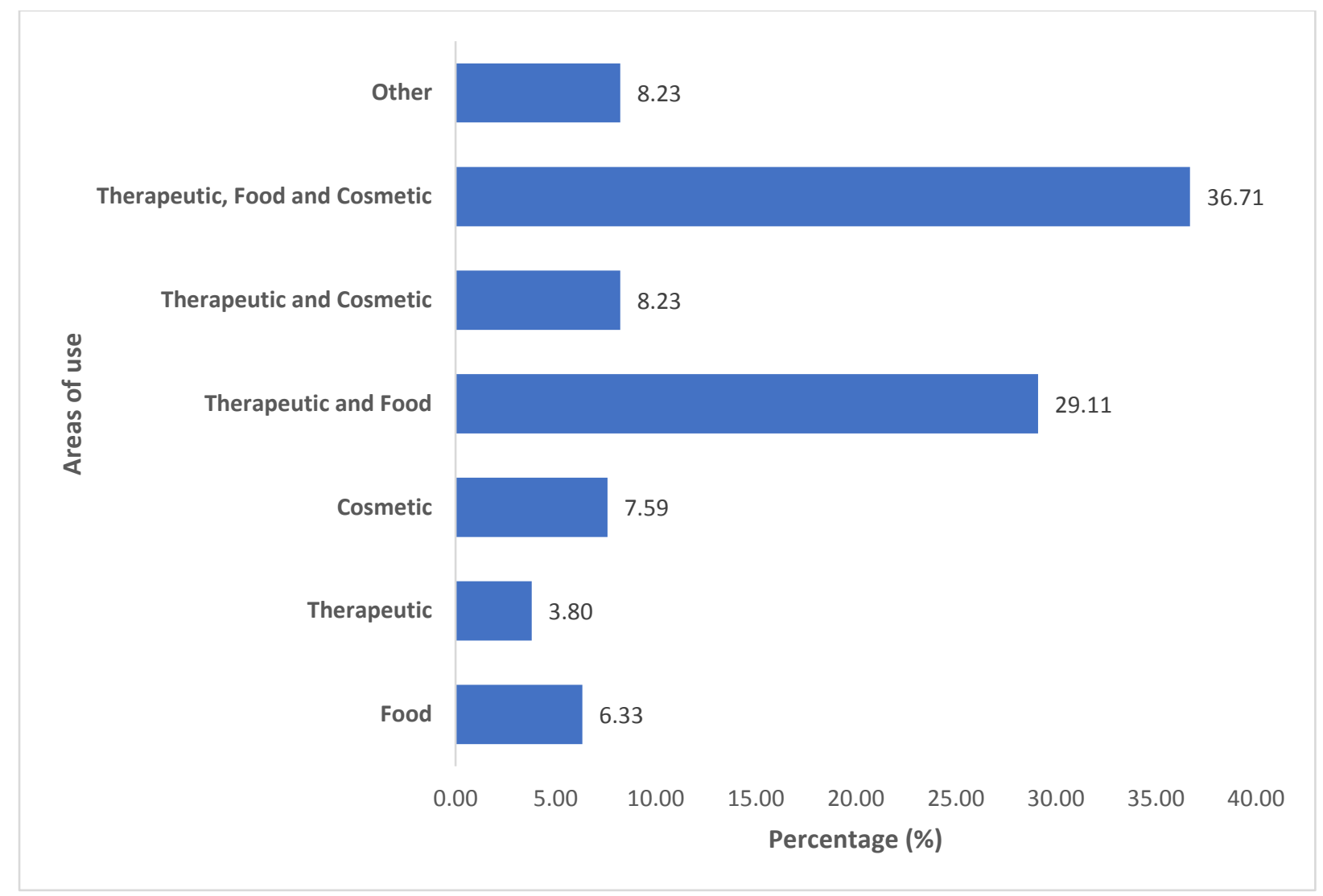

Fig. 12. Areas of use of natural dyes

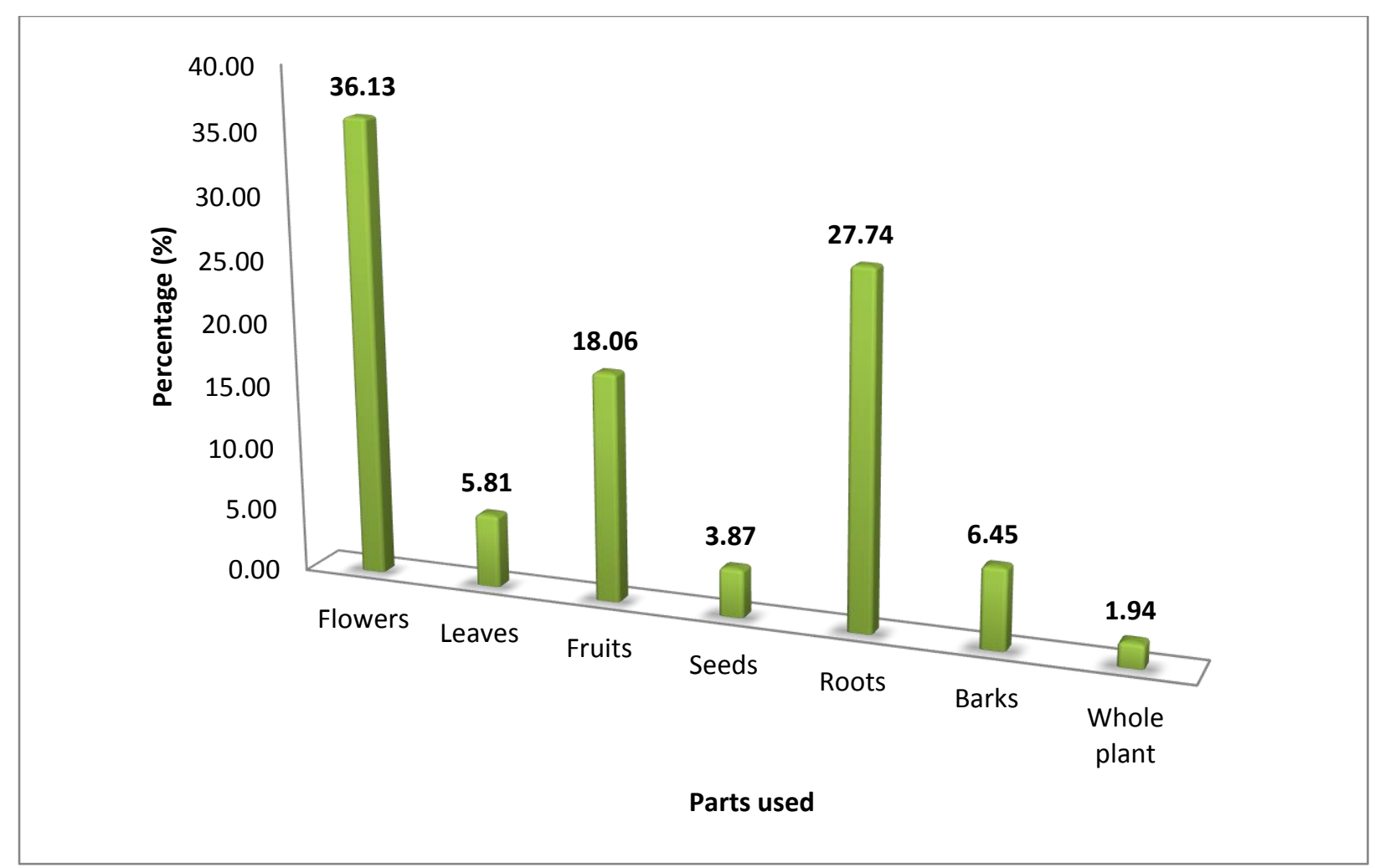

Fig. 13. Parts used 


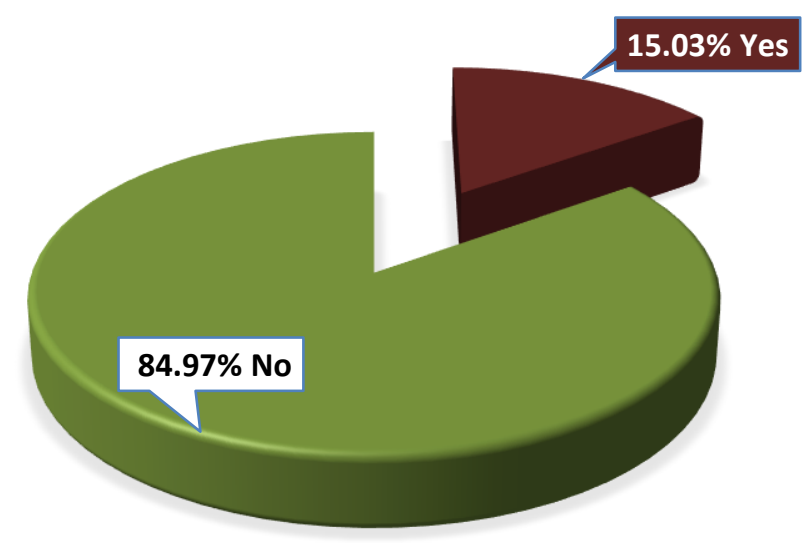

Fig. 14. Side effects

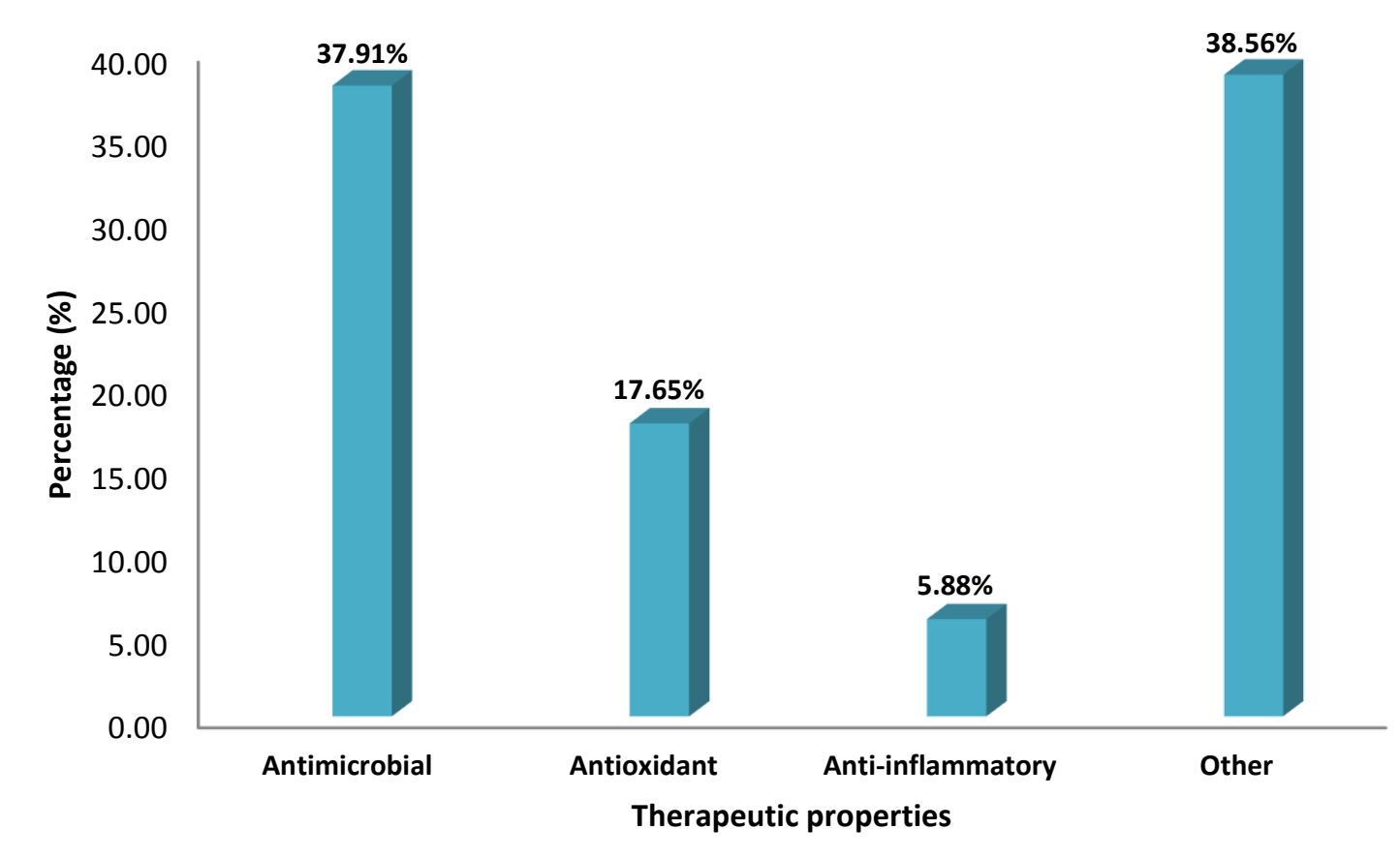

Fig. 15. Therapeutic properties 


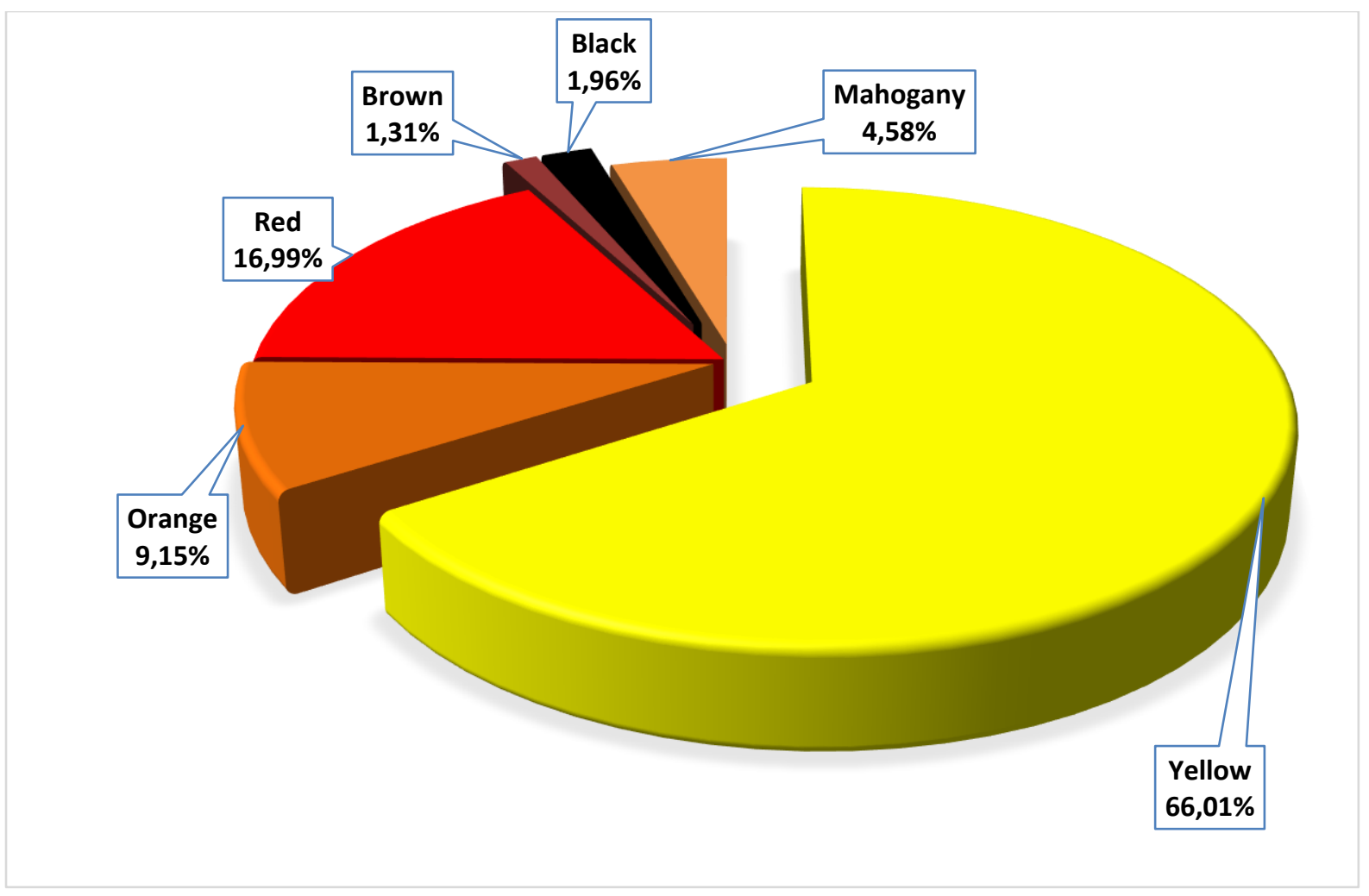

Fig. 16. Colours

\section{Other properties of the tinctorial plants}

The properties for which plant-based dyes are exploited by the population surveyed are illustrated in figure 17 ; we find that $42.86 \%$ of users employ them for their therapeutic, cosmetic and other unidentified properties, followed by $29.87 \%$ of those in the study area who use them to modify the taste, again as the aroma and curator with a percentage of $14,29 \%$ and $12,99 \%$ respectively.

\section{Multivariate analysis of information on plants used by the population surveyed by PCA}

Figure 18 shows the PCA based on all the data collected on plants use in each study region as sources of natural food additives.

The two axes (F1XF2) taken into account to describe the correlations between variables related to plant use as a source of natural additives alone holds $59.07 \%$ of the total information, with $21.07 \%$ for axis 1 and $37.99 \%$ respectively for Axis 2 (Fig. 18). This figure shows that all variables are presented in the circle and that the typological structure of the F1xF2 plan (Fig. 18) shows the individualization of four groups according to their degree of correlation:

- At the Taza, Azrou and Midelt provinces, the population surveyed uses plants as spices for food and weaving.

- At the El Hajeb, Ain Leuh and Ifrane provinces, the local population uses natural food additives in the field of cosmetology not only for facials, body, hair and make-up but also for their organic properties: antifungal and anti-dermatological.

- The surveyed population of the city of Meknes uses plants mainly as natural dyes and preservatives in different foodstuffs, as well as for hair care. The use of dye and organic preservatives is justified by the public's mistrust of synthetic additives. On the other hand, plants in this region are estimated as a plant of high therapeutic value.

- The population of the provinces of Boulemane and M'rirt uses natural resources in particular aromatic and medicinal plants for their therapeutic properties, as the socio-economic and climatic situation are difficult for these Populations. 


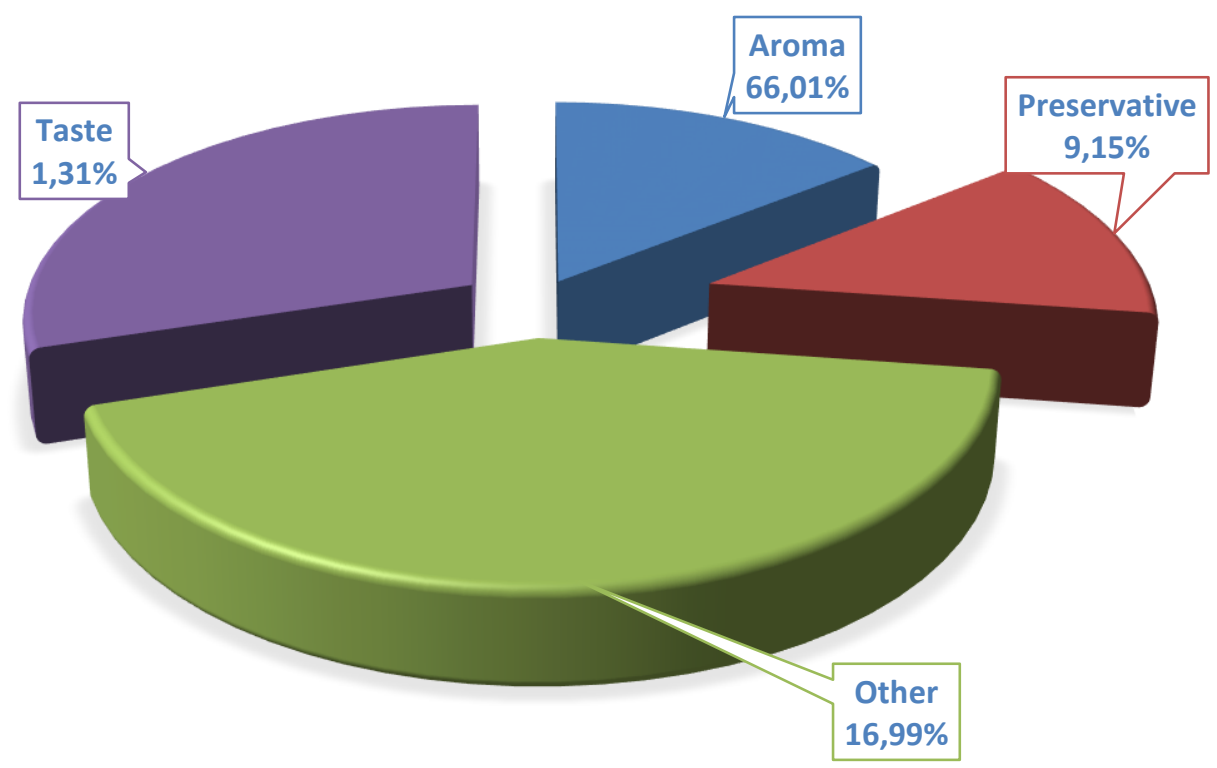

Fig. 17. Other uses of coloring plants

Biplot (axes F1 et F2 : 59,07\%)

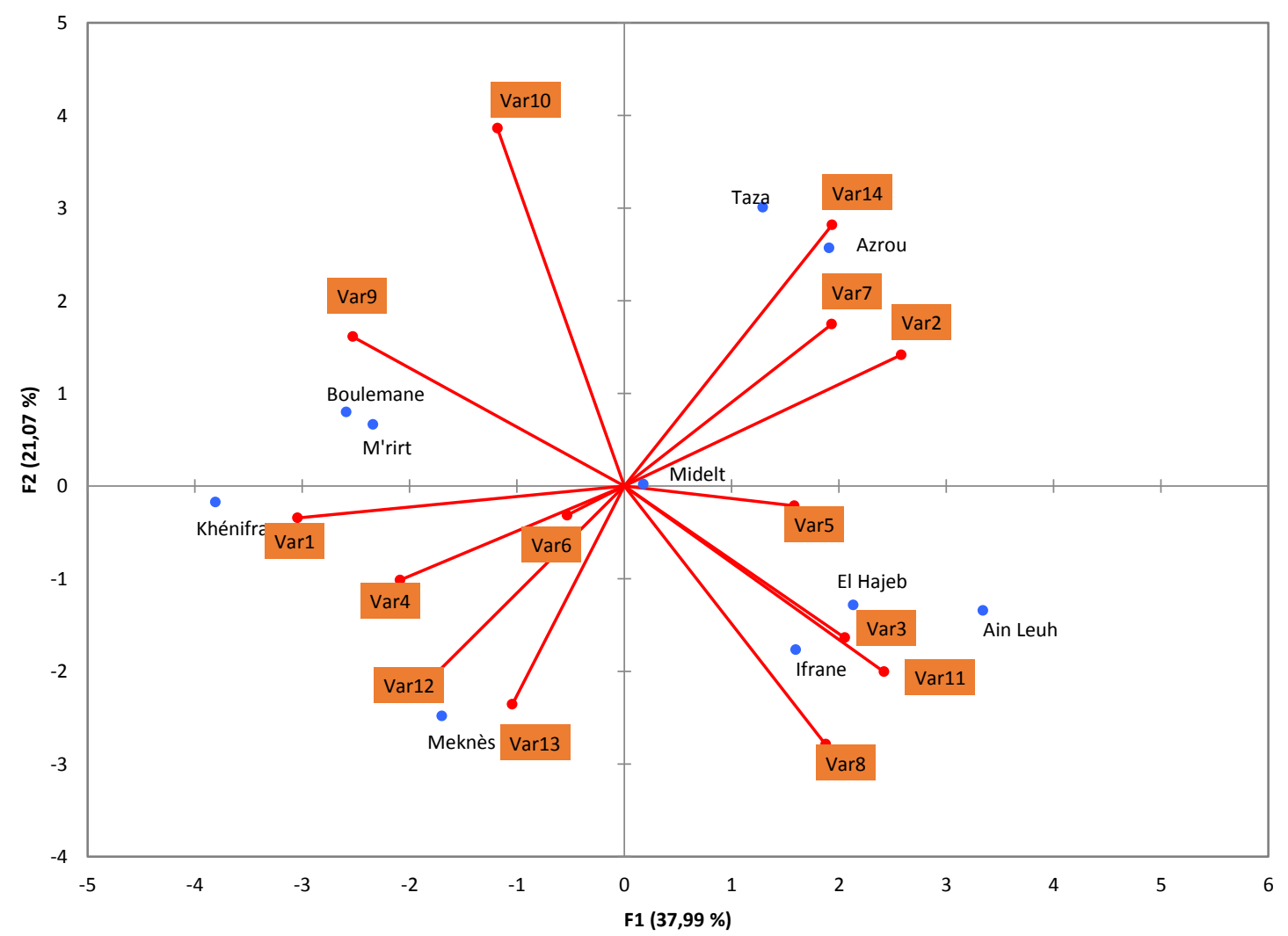

Fig. 18: Graphical Approach to Principal Component Analysis According to the Plan (F1xF2) (Areas of plant use variable: var 1: therapeutic, var 2: food, var3: cosmetics. Food use variable: var 4: dyes, var5: dyes, var 6: preservatives, var 7: spices. Therapeutic properties of coloring plants variables: var 8: antimicrobials, var 9: antioxidants, var 10: anti-inflammatories, var11: other pharmacological properties.Use of natural dyes variables: var 12: food, var13: hair, var14: weaving). 


\section{Conclusion}

This study identified 56 AMP already exploited in traditional Moroccan pharmacopeia as colouring plants. These can replace synthetic dyes and, thus, be used as natural additives on an industrial scale. At the same time, it is clear that this inventory can be considered as a source of information contributing to a better knowledge of Moroccan medicinal flora and local popular know-how. It can also provide a database for the recovery of tinctorial plants in different fields other than herbal medicine. Finally, the information acquired from the questionnaire sheets, led to production of a catalogue of 79 plant species, whose monographs are presented in alphabetical order of families, genres and species. Indeed, for each species, we specified the systematic position, the French vernacular name, the Arabic vernacular name, pharmacological properties, traditional local use and its toxicity (appendix 4). Knowing that natural pigments offer a strong advantage over synthetic pigments, it is necessary to study their safety and evaluate all their effects in order to conclusively demonstrate their beneficial effects on health.

\section{Declarations}

List of abbreviations: Not applicable.

Ethics approval and consent to participate: The purpose of the study was explained to the community members interviewed. Respondents were not asked to sign a particular consent form as the questionnaire was anonymous.

Availability of data and materials: The data was not deposited in public repositories.

Consent for publication: Not applicable.

Competing interests: The authors do not have any competing interests.

Funding: The ethnobotanical study of natural food additives of plant source was initiated within the framework of a project sponsored by the Somafaco Company. Later, this work was developed in the form of a topic for academic research (thesis). At this stage, the doctoral student Aziz Drioiche expanded and completed the fieldwork in other areas of Morocco within the framework of the project sponsored by the Fez Meknes region.

Author contributions: The co-authors participated in the research for this ethnobotanical study (fieldwork to complete the questionnaire). Pr. Zair Touriya is the coordinator of the two research projects (Somafaco and region) and supervised the research work of Aziz Drioiche. Moukaid Braim is the scientific representative of Somafaco who took part in discussions related to the project and the article.

\section{Acknowledgments}

We would like to express our gratitude and thanks to all the institutions and members who contributed to the realization and success of this study, we cite in particular the Fez-Meknes Region, the Somafaco company, the cooperatives of the regions of Ifrane and Boulemane, as well as Pr. Mr. Khamar Hamid of the scientific institute of Rabat.

\section{Literature cited}

Abasher AM, Adam MA, Hassan HI, Kamal-eldin A. 2014. Review: Biochemical composition and medicinal uses of chrozophora genus. International Journal of Pharmacy Review \& Research 4(4): 227232.

Abdulmumeen, H.A., Risikat, A.N., Agboola R Sururah, 2012. Food: Its preservatives, additives and applications. Journal of Chemical and Biochemical Sciences 36-47. https://doi.org/10.13140/2.1.1623.5208.

Abiri R, Silva ALM, De Mesquita LSS, De Mesquita JWC, Atabaki N, De Almeida EB, Shaharuddin NA, Malik S. 2018. Towards a better understanding of Artemisia vulgaris: Botany, phytochemistry, pharmacological and biotechnological potential. Food Research International 109: 403-415. https://doi.org/10.1016/j.foodres.2018.03.072

Adachi H, Nakae K, Sakamoto S, Nosaka C, Atsumi $\mathrm{S}$, Shibuya M, Higashi N, Nakajima M, Irimura T, Nishimura Y. 2018. Microbial metabolites and derivatives targeted at inflammation and bone diseases therapy: chemistry, biological activity and pharmacology. The Journal of antibiotics 71: 60-71. https://doi.org/10.1038/ja.2017.138

Adjanohoun EJ, Ahyi AMR., Aké Assi L, Baniakina J, Chibon P, Cusset G, Doulou V, Enzanza A, Eymé J, Goudoté E, Keita A, Mbemba C, Mollet J, Moutsamboté JM, Mpati J \& Sita P. (Editors), 1988. Médecine traditionnelle et pharmacopée Contribution aux études ethnobotaniques et floristiques en République Populaire du Congo. Agence de Coopération Culturelle et Technique, Paris, France. 606 pp.

Ait-Sidi-Brahim M, Markouk M, Larhsini M. 2019. Chapter 5 - Moroccan Medicinal Plants as Antiinfective and Antioxidant Agents. In: Ahmad Khan MS, Ahmad I, Chattopadhyay D, editors. New Look to Phytomedicine: Academic Press: 91-142. https://doi.org/10.1016/B978-0-12-814619-4.000057.

Alia BH, Bashir AK, Tanira MOM. 1995. AntiInflammatory, Antipyretic, and Analgesic Effects of Lawsonia inermis L. (Henna) in Rats. Pharmacology 51: 356-363. https://doi.org/10.1159/000139347.

AI-Snafi AE 2016. The medical Importance of Cicer arietinum-A review. IOSR Journal of Pharmacy 6 (3): 29-40.

Amorini E, Bruschini S, Cutini A, Lorenzo MG Di, Fabbio G. 1996. Treatment of Turkey oak (Quercus cerris L.) coppices. Structure, biomass and silvicultural options. Annali Istituto Sperimentale per la Selvicoltura 27: 121-129. 
Anderson WR, Cronquist A. 1982. An Integrated System of Classification of Flowering Plants. Brittonia 34: 268. https://doi.org/10.2307/2806386

Anyinam C. 1995. Ecology and ethnomedicine: exploring links between current environmental crisis and indigenous medical practices. Social Science \& Medicine 40(3):321-329. doi: 10.1016/02779536(94)e0098-d

Arun N, Singh DP. 2012. Punica granatum: a review on pharmacological and therapeutic properties. International Journal of Pharmaceutical Sciences and Research 3:1240-5. DOI: 10.4103/0972124X.138678

Asgarpanah J, Kazemivash N. 2013. Phytochemistry, pharmacology and medicinal properties of Carthamus tinctorius L. Chinese Journal of Integrative Medicine 19: 153-159. https://doi.org/10.1007/s11655-013-1354-5

Asgarpanah J, Mohajerani R. 2012. Phytochemistry and pharmacologic properties of Urtica dioica $\mathrm{L}$. Journal of Medicinal Plants Research 6(46): 57145719. https://doi.org/10.5897/JMPR12.540

Asgarpanah J, Ramezanloo F. 2012. Chemistry, pharmacology and medicinal properties of Peganum harmala L. African Journal of Pharmacy and Pharmacology 6(22), 1573-1580. https://doi.org/10.5897/AJPP11.876

Ashraf DK, 2018. A comprehensive review on Curcuma longa Linn.: Phytochemical, pharmacological, and molecular study. International Journal of Green Pharmacy 11: $\quad$ S672. https://doi.org/10.22377/ijgp.v11i04.1343

Aslam H, Khan A, Naureen H, Ali F, Ullah F, Sadiq A. 2018. Potential application of Conyza canadensis (L) Cronquist in the management of diabetes: In vitro and in vivo evaluation. Tropical Journal of Pharmaceutical Research 17 (7): 1287-1293. http://dx.doi.org/10.4314/tjpr.v17i7.9

Badgujar SB, Patel VV, Bandivdekar AH, Mahajan RT. 2014. Traditional uses, phytochemistry and pharmacology of Ficus carica: A review. Pharmaceutical Biology 52(11): 1487-1503. https://doi.org/10.3109/13880209.2014.892515

Bammou M, Daoudi A, Sellam K, Rhaffari LE, Ibijbijen J, Nassiri L. 2015. Ethnobotanical Survey of Asteraceae Family used in Meknes - Tafilalet Region (Morocco). International Journal of Innovation and Applied Studies $13:$ 789-815.

Béatrice DR. 2009. Additifs et auxiliaires de fabrication dans les industries agroalimentaires (4e ed.). Lavoisier.

Benkhnigue O, Ben Akka F, Salhi S, Fadli M, Douira A, Zidane L. 2014. Catalogue des plantes médicinales utilisées dans le traitement du diabète dans la région d'Al Haouz-Rhamna (Maroc). Journal of Animal and Plant Sciences 23 (1): 3539-68.
Benkhnigue $\mathrm{O}$, Zidane L, Fadli $\mathrm{M}$, Elyacoubi $\mathrm{H}$, Rochdi A, Douira A. 2010. Etude ethnobotanique des plantes médicinales dans la région de Mechraâ Bel Ksiri (Région du Gharb du Maroc). Acta Botanica Barcinonensia 53 : 191-216.

Benlamdini N, Elhafian M, Rochdi A, Zidane L. 2014. Étude floristique et ethnobotanique de la flore médicinale du Haut Atlas oriental (Haute Moulouya). Journal of Applied Biosciences 78 (1): 6771. https://doi.org/10.4314/jab.v78i1.17

Botineau M. 2011. Botanique systématique et appliquée des plantes à fleurs. Tech et Doc, Lavoisier.

Bouquet A. 1969. Féticheurs et médecines traditionnelles du Congo (Brazzaville), Mémoires ORSTOM. ORS-TOM, Paris.

Bouyahya A, Dakka N, Talbaoui A, Moussaoui NE, Abrini J, Bakri Y. 2018. Phenolic contents and antiradical capacity of vegetable oil from Pistacia lentiscus (L). Journal of Materials and Environmental Science 9(5): 1518-1524.

Bozorgi M, Memariani Z, Mobli M, Salehi Surmaghi $\mathrm{MH}$, Shams-Ardekani MR, Rahimi R. 2013. Five Pistacia species ( $P$. vera, $P$. atlantica, $P$. terebinthus, $P$. khinjuk, and $P$. lentiscus): A Review of Their Traditional Uses, Phytochemistry, and Pharmacology. The Scientific World Journal (1):219815. https://doi.org/10.1155/2013/219815

Bradic J, Petkovic A, Tomovic M. 2018. Phytochemical and Pharmacological Properties of Some Species of the Genus Galium L. Galium Verum and Mollugo. Serbian Journal of Experimental and Clinical Research:1-7. doi: 10.1515/sjecr-20170057.

Chaudhary NK. 2010. Food Additives. Bibechana 6: 22-26. https://doi.org/10.3126/bibechana.v6i0.3935

Chengaiah B, Rao KM, Kumar KM, Alagusundaram M, Chetty CM. 2010. Medicinal Importance of Natural Dyes - A Review. International Journal of PharmTech Research 2(1): 144-154.

Cottigli F, Loy G, Garau D, Floris C, Caus M, Pompei $R$, Bonsignore L. 2001. Antimicrobial evaluation of coumarins and flavonoids from the stems of Daphne gnidium L. Phytomedicine 8: 302-305. https://doi.org/10.1078/0944-7113-00036

Cottiglia F, Bonsignore L, Loy G, Garau D, Floris C, Casu M. 2002. Structure elucidation and antibacterial activity of a new coumarinolignoid from Daphne gnidium L. Magnetic Resonance in Chemistry 40: 551-553. https://doi.org/10.1002/mrc.1047

Dikshit R, Tallapragada P. 2018. Chapter 3 Comparative Study of Natural and Artificial Flavoring Agents and Dyes, in: Grumezescu, A.M., Holban, A.M. (Eds.), Natural and Artificial Flavoring Agents 
and Food Dyes, Handbook of Food Bioengineering. Academic Press: 83-111. https://doi.org/10.1016/B978-0-12-811518-3.00003$\mathrm{X}$

Dorsch W. 1997. Allium cepa L (Onion): Part 2 chemistry, analysis and pharmacology. Phytomedicine 3: 391-397. https://doi.org/10.1016/S0944-7113(97)80014-1

Dupont, F., Guignard, J-L, 2015. "Botanique: les familles de plantes". Elsevier Masson. Issy-lesMoulineaux, 336p.

Dzabijeva D, Boroduske A, Ramata-Stunda A, Mazarova N, Nikolajeva V, Boroduskis M, Nakurte I. 2018. Anti-Bacterial Activity and Online HPLC-DPPH Based Antiradical Kinetics of Medicinal Plant Extracts of High Relevance for Cosmetics Production. Key Engineering Materials 762: 8-13. https://doi.org/10.4028/www.scientific.net/KEM.762. 8

Eddouks M, Ajebli M, Hebi M. 2017. Ethnopharmacological survey of medicinal plants used in Daraa-Tafilalet region (Province of Errachidia), Morocco. Journal of Ethnopharmacology. 198: 516-530.

El Amri J, El Badaoui K, Zair T, Bouharb H, Chakir S, Alaoui TEM. 2015. Ethnobotanical study of medicinal plants in the region El Hajeb (central Morocco). Journal of Biological Research 4: 156880.

El Hilah Fatima FBA, Dahmani J, Belahbib N, Zidane L. 2015. Étude ethnobotanique des plantes médicinales utilisées dans le traitement des infections du système respiratoire dans le plateau central maro-cain. Journal of Animal and Plant Sciences $25:$ 3886-3897.

Elazzouzi H, Khabbal Y, Bouachrine M, Zair T, Belghiti MAE. 2018. Chemical composition and in vitro antibacterial activity of Artemisia ifranensis $\mathrm{J}$. Didier essential oil Growing Wild in Middle Moroccan Atlas. Journal of Essential Oil Research 30: 142151.

https://doi.org/10.1080/10412905.2017.1420552

Errajraji A, Ouhdouch F, El-Anssari N. 2010. Usage des plantes médicinales dans le traitement du diabète de type 2 au Maroc. Médecine des Maladies Métaboliques 4(3), 301-304.

Fennane M., 2004. Zones importantes de plantes au maroc 25.

Fennane M. 1999. Observations sur la flore vasculaire endémique, rare ou menacée du Maroc. Flora Mediterr. 12

Fennane M. 1998. Catalogue des plantes vasculaires rares, menacées ou endémiques du Maroc 7.

Fiolet T, Srour B, Sellem L, Kesse-Guyot E, Allès B, Méjean C, Deschasaux M, Fassier P, Latino-Martel
P, Beslay M, Hercberg S, Lavalette C, Monteiro CA, Julia C, Touvier M. 2018. Consumption of ultraprocessed foods and cancer risk: results from NutriNet-Santé prospective cohort. British Medical Journal 360: k322. https://doi.org/10.1136/bmj.k322

Garbacki N, Gloaguen V, Damas J, Bodart P, Tits M, Angenot L. 1999. Anti-inflammatory and immunological effects of Centaurea cyanus flower-heads. Journal of Ethnopharmacology 68(1-3):235-241. https://doi.org/10.1016/S0378-8741(99)00112-9

Gilani AH, Mehmood MH, Janbaz KH, Khan A, Saeed SA. 2008. Ethnopharmacological studies on antispasmodic and antiplatelet activities of Ficus carica. Journal of Ethnopharmacology 119(1): 1-5. https://doi.org/10.1016/j.jep.2008.05.040

Gilani AH, Yaeesh S, Jamal Q, Ghayur MN. 2005. Hepatoprotective activity of aqueous-methanol extract of Artemisia vulgaris. Phytotherapy Research 19(2): 170-172. https://doi.org/10.1002/ptr.1632

Goktas O, Ozen E, Baysal E, Mammadov R, Alma $\mathrm{MH}$, Sonmez A. 2009. Color stability of wood treated with madder root (Rubia tinctorium L.) extract after lightfastness test. Wood Research 54 (1), 37-44.

Gürbüz İ, Üstün O, Yesilada E, Sezik E, Kutsal O. 2003. Anti-ulcerogenic activity of some plants used as folk remedy in Turkey. Journal of Ethnopharmacology 88 :93-97. https://doi.org/10.1016/S0378-8741(03)00174-0

Hamel T, Sadou S, Seridi R, Boukhdir S, Boulemtafes A. 2018. Pratique traditionnelle d'utilisation des plantes médicinales dans la population de la péninsule de l'edough (nord-est algérien). Ethnopharmacologia 59 : 75-81.

Hmamouchi M. 2001. Les plantes médicinales et aromatiques marocaines. Utilisations traditionnelles, Marché, Biologie, Chimie, Pharmacologie, Toxicologie, Lexique. $2 e$ édition Fédala Mohammedia Maroc, $450 \mathrm{p}$.

Hmiri S, Rahouti M, Habib Z, Satrani B, Ghanmi M, El Ajjouri M. 2011. Évaluation du potentiel antifongique des huiles essentielles de Mentha pulegium et d'Eucalyptus camaldulensis dans la lutte biologique contre les champignons responsables de la détérioration des pommes en conservation. Bulletin de la Société Royale des Sciences de Liège. $80: 824-836$.

Hosseini A, Razavi BM, Hosseinzadeh H. 2018. Saffron (Crocus sativus) petal as a new pharmacological target: a review. Iranian Journal of Basic Medical Sciences 21: 1091-1099. https://doi.org/10.22038/IJBMS.2018.31243.7529

Hughes BG, Lawson LD. 1991. Antimicrobial effects of Allium sativum L. (garlic), Allium ampeloprasum $\mathrm{L}$. (elephant garlic), and Allium cepa L. (onion), garlic compounds and commercial garlic supplement products. Phytotherapy Research 5: 154-158. https://doi.org/10.1002/ptr.2650050403 
Izzat SS. 2017. A Surveillance study on the presence and safety of different types of food additive in children's foods available in the markets. Journal of Zankoy Sulaimani 19:1.

Jamil QUA, Iqbal SM, Jaeger W, Studenik C. 2018. Vasodilating, spasmolytic, inotropic and chronotropic activities of curcuminoids from Curcuma longa in isolated organ preparations of guinea pigs. Journal of Physiology and Pharmacology 69(3). https://doi.org/10.26402/jpp.2018.3.10

Joint order of the Minister of Agriculture and Maritime Fisheries and the Minister of Health $n{ }^{\circ}$ of 14 rejeb 1435 (14 May 2014) fixing the list and limits of authorized food additives, ND (BO $n$ 6322bis of 01/01 / 2015, page 425)

Jouad H, Haloui M, Rhiouani H, El Hilaly J, Eddouks M. 2001. Ethnobotanical survey of medicinal plants used for the treatment of diabetes, cardiac and renal diseases in the North centre region of Morocco (FezBoulemane). Journal of Ethnopharmacology 77(2_3) : 175-182. https://doi.org/10.1016/S03788741(01)00289-6

Jung Y, Kim B, Ryu MH, Kim H. 2018. Chinese medicines reported to have effects on contact dermatitis in the last 20 years. Chinese Journal of Integrative Medicine 24: 64-71. https://doi.org/10.1007/s11655-016-2535-9

Kalvachev YA, Hayashi T, Tsubota S, Haruta M. 1997. Selective partial oxidation of propylene-topropylene oxide on Au/Ti-MCM catalysts in the presence of hydrogen and oxygen, in: Studies in Surface Science and Catalysis. Elsevier, pp. 965972.

Kimpouni V. 2001. Contribution aux études ethnobotaniques et floristiques de la forêt de Lossi (R.P. Congo) : les plantes de cueillette à usage alimentaire. Systematics and Geography of Plants 71: 679-686. https://doi.org/10.2307/3668710

Kondo K, Takaishi Y, Shibata H, Higuti T. 2006. ILSMRs (intensifier of $\beta$-lactam-susceptibility in methicil-lin-resistant Staphylococcus aureus) from Tara [Caesalpinia spinosa (Molina) Kuntze]. Phytomedicine 13: 209-212. https://doi.org/10.1016/j.phymed.2004.08.001

Kundal J, Vir Singh S. 2016. Extraction of Natural Dye from Ficus cunia and Dyeing of Polyester Cotton and Wool Fabric Using Different Mordants, with Evaluation of Colour Fastness PropertiesNatural Products Chemistry and Research $4: 3$ https://doi.org/10.4172/2329-6836.1000214

Lahsissene H, Kahouadji A, Hseini S. 2009. Catalogue des plantes medicinales utilisees dans la region de Zaër (Maroc Occidental). Lejeunia, Revue de Botanique 186.

Lansky EP, Newman RA. 2007. Punica granatum (pomegranate) and its potential for prevention and treatment of inflammation and cancer. Journal of $\begin{array}{lcc}\text { Ethnopharmacology } & 109(2): & 177-206 . \\ \text { https://doi.org/10.1016/j.jep.2006.09.006 } & \end{array}$

Lateef R, Bhat KA, Chandra S, Banday JA. 2018. Chemical composition, antimicrobial and antioxidant activities of the essential oil of Conyza canadensis growing wild in Kashmir valley. American Journal of Essential Oils and Natural Products 6(1): 35-41.

Lemhadri A, Zeggwagh NA, Maghrani M, Jouad H, Eddouks M. 2004. Anti-hyperglycaemic activity of the aqueous extract of Origanum vulgare growing wild in Tafilalet region. Journal of Ethnopharmacology 92(23):251-256.

https://doi.org/10.1016/j.jep.2004.02.026

Lordani TVA, de Lara CE, Ferreira FBP, de Souza Terron Monich M, Mesquita da Silva C, Felicetti Lordani CR, Giacomini Bueno F, Vieira Teixeira JJ, Lonardoni MVC. 2018. Therapeutic Effects of Medicinal Plants on Cutaneous Wound Healing in Humans: A Systematic Review. Mediators of Inflammation https://doi.org/10.1155/2018/7354250

Majer A. 1984. The ecological relations of Turkey oak (Quercus cerris). Folia Dendrologica 11: 331345.

Mantle D, Gok MA, Lennard TW. 2001. Adverse and beneficial effects of plant extracts on skin and skin disorders. Adverse Drug React. Toxicological Reviews 20: 89-103.

Matić S. 2000. Oak forests (Quercus sp.) in Croatia. Glasnik za šumske pokuse 37: 5-13.

Maurya H, Semwal M, Dubey SK. 2016. Pharmacological Evaluation of Chrozophora tinctoria as Wound Healing Potential in Diabetic Rat's Model. BioMed Research International (14):1-7. https://doi.org/10.1155/2016/7475124

Mehdioui R, Kahouadji A. 2007. Etude ethnobotanique auprès de la population riveraine de la forêt d'Amsittène: cas de la Commune d'Imi n'Tlit (Province d'Essaouira). Bulletin de I'Institut scientifique, Rabat, section Sciences de la vie 3:1120.

Mishchenko NP, Fedoreev SA, Bryukhanov VM, Zverev YaF, Lampatov VV, Azarova OV, Shkryl' YuN, Chernoded GK. 2007. Chemical composition and pharmacological activity of anthraquinones from Rubia cordifolia cell culture. Pharmaceutical Chemistry Journal 41: 605-609. https://doi.org/10.1007/s11094-008-0021-1

Mockute D, Bernotiene G, Judzentiene A. 2001. The essential oil of Origanum vulgare L. ssp. vulgare growing wild in Vilnius district (Lithuania). Phytochemistry 57: 65-69. https://doi.org/10.1016/S0031-9422(00)00474-X

Motte E. 1980. Les plantes chez les pygmées Aka et les Monzombo de la Lobaye (Centrafrique): contribution à une étude ethnobotanique 
comparative chez des chasseurs-cueilleurs et des pêcheurs-cultivateurs vivant dans un même milieu végétal. Paris, Société d'études linguistiques et anthropologiques de France (Series) : 80-82.

Msagati TAM. 2012. The Chemistry of Food Additives and Preservatives. John Wiley \& Sons. DOI:10.1002/9781118274132

Muley BP, Khadabadi SS, Banarase NB. 2009. Phytochemical Constituents and Pharmacological Activi-ties of Calendula officinalis Linn (Asteraceae): A Review. Tropical Journal of Pharmaceutical $\begin{array}{llll}\text { Research } & 8 & (5): & 455-465 .\end{array}$ https://doi.org/10.4314/tjpr.v8i5.48090

Omer SA, Elobeid MA, Elamin MH, Hassan Z, Virk $\mathrm{P}$, Daghestani M, Al-Olayan E, Al-Eisa NA, Almarhoon Z. 2012. Toxicity of olive leaves (Olea europaea L.) in Wistar albino rats. Asian Journal of Animal and Veterinary Advances (11): 1175-1182. DOI: 10.3923/ajava.2012.1175.1182

Ouelbani R, Bensari S, Mouas TN, Khelifi D. 2016. Ethnobotanical investigations on plants used in folk medicine in the regions of Constantine and Mila (North-East of Algeria). Journal of Ethnopharmacology 194: 196-218. doi: 10.1016/j.jep.2016.08.016

Pirvu L, Dragomir C, Schiopu S, Mihul C. 2012. Vegetal extracts with gastroprotective activity. Part. I. Ex-tracts obtained from Centaurea cyanus L. raw material. Romanian Biotechnological Letters 17(2): 9.

Prakash D, Singh BN, Upadhyay G. 2007.

Antioxidant and free radical scavenging activities of phenols from onion (Allium cepa). Food Chemistry. 102: 1389-1393.

https://doi.org/10.1016/j.foodchem.2006.06.063

Raponda-walker A, Sillans R. 1961. Les Plantes Utiles Du Gabon. Quarterly Journal of Crude Drug Research $1: 27$. https://doi.org/10.3109/13880206109066644

Riaz G, Chopra R. 2018. A review on phytochemistry and therapeutic uses of Hibiscus sabdariffa $\mathrm{L}$. Biomedicine \& Pharmacotherapy 102: 575-586. https://doi.org/10.1016/j.biopha.2018.03.023

Roach DA, Wulff RD. 1987. Maternal Effects in Plants. Annual Review of Ecology, Evolution, and Systematics 18: 209-235. https://doi.org/10.1146/annurev.es.18.110187.0012 33

Salhi, N., Bouyahya, A., Fettach, S., Zellou, A., Cherrah, Y., 2019. Ethnopharmacological study of medicinal plants used in the treatment of skin burns in occidental Morocco (area of Rabat). South African Journal of Botany 121: 128-142. https://doi.org/10.1016/j.sajb.2018.10.038

Seung TW, Park SK, Kang JY, Kim JM, Park SH, Kwon BS, Lee CJ, Kang JE, Kim DO, Lee U, Heo,
HJ. 2018. Ethyl acetate fraction from Hibiscus sabdariffa L. attenuates diabetes-associated cognitive impairment in mice. Food Research International 105: 589-598. https://doi.org/10.1016/j.foodres.2017.11.063

Shafaghat A, Salimi F, Aslaniyan N, Shoaei Z. 2010. Flavonoids and an ester derivative isolated from Galium verum L. World Applied Sciences Journal 11: 473-477.

Shanker AK, Cervantes C, Loza-Tavera H, Avudainayagam S. 2005. Chromium toxicity in plants. Environment International 31(5): 739-753. https://doi.org/10.1016/j.envint.2005.02.003

Silva, E., Fernandes, S., Bacelar, E., Sampaio, A., 2016. Antimicrobial activity of aqueous, ethanolic and methanolic leaf extracts from acacia spp. And Eucalyptus nicholii. African Journal of Traditional, Complementary and Alternative Medicines 13(6): 130-134. https://doi.org/10.21010/ajtcam.v13i6.18

Singh DK, Luqman S, Mathur AK. 2015. Lawsonia inermis L. - A commercially important primaeval dying and medicinal plant with diverse pharmacological activity: A review. Industrial Crops and Products 65, 269-286. https://doi.org/10.1016/j.indcrop.2014.11.025

Skowyra M, Falguera V, Gallego G, Peiró S, Almajano MP. 2014. Antioxidant properties of aqueous and ethanolic extracts of tara (Caesalpinia spinosa) pods in vitro and in model food emulsions. Journal of the Science of Food and Agriculture 94(5): 911-918. https://doi.org/10.1002/jsfa.6335

Soulimani R, Younos C, Jarmouni-Idrissi S, Bousta D, Khalouki F, Laila A. 2001. Behavioral and pharmaco-toxicological study of Papaver rhoeas $L$. in mice. Journal of Ethnopharmacology 74(3): 265274. https://doi.org/10.1016/S0378-8741(00)003834

Su CC, Wang CJ, Huang KH, Lee YJ, Chan WM, Chang YC. 2018. Anthocyanins from Hibiscus sabdariffa calyx attenuate in vitro and in vivo melanoma cancer metastasis. Journal of Functional Foods 48: 614-631. https://doi.org/10.1016/j.jff.2018.07.032

Subhan N, Burrows GE, Kerr PG, Obied HK. 2018. Chapter 9 - Phytochemistry, Ethnomedicine, and Pharmacology of Acacia, in: Atta-ur-Rahman (Ed.), Studies in Natural Products Chemistry. Elsevier, pp. 247-326. https://doi.org/10.1016/B978-0-44464057-4.00009-0

Takkouche B, Etminan M, Montes-Martínez A. 2005. Personal Use of Hair Dyes and Risk of Cancer: A Meta-analysis. Journal of the American Medical Association 293(20): 2516-2525. https://doi.org/10.1001/jama.293.20.2516

Testai L, Chericoni S, Calderone V, Nencioni G, Nieri P, Morelli I, Martinotti E. 2002. Cardiovascular effects of Urtica dioica L. (Urticaceae) roots extracts: 
in vitro and in vivo pharmacological studies. Journal of Ethnopharmacology 81(1): 105-109. https://doi.org/10.1016/S0378-8741(02)00055-7

Urueña C, Mancipe J, Hernandez J, Castañeda D, Pombo L, Gomez A, Asea A, Fiorentino S. 2013. Gallotannin-rich Caesalpinia spinosa fraction decreases the primary tumor and factors associated with poor prognosis in a murine breast cancer model. BMC Complementary Medicine and Therapies 13: 74. https://doi.org/10.1186/1472-6882-13-74

Vitalini S, Iriti M, Puricelli C, Ciuchi D, Segale A, Fico G. 2013. Traditional knowledge on medicinal and food plants used in Val San Giacomo (Sondrio, Italy)-An alpine ethnobotanical study. Journal of Ethnopharmacology 145(2): 517-529.

Whitman BW, Ghazizadeh H. 1994. Eucalyptus Oil: Therapeutic and Toxic Aspects of Pharmacology in Humans and Animals. Journal of Paediatrics and Child Health 30(2): 190-191. https://doi.org/10.1111/j.1440-1754.1994.tb00613.x

Zakariya I, Ifezouane J, Addaoui A, Skalli S, Bouslimane Y. 2018. Evaluation of the therapeutic and toxicological knowledge of herbalists on the most notified plants in the poison control and pharmaco-vigilance center of Morocco. Journal of Pharmacognosy and Phytotherapy 10: 126-132. https://doi.org/10.5897/JPP2018.0507

Zitterl-Eglseer K, Sosa S, Jurenitsch J, SchubertZsilavecz M, Della Loggia R, Tubaro A, Bertoldi M, Franz C. 1997. Anti-oedematous activities of the main triterpendiol esters of marigold (Calendula officinalis L.). Journal of Ethnopharmacology 57(2): 139-144. https://doi.org/10.1016/S0378-

8741(97)00061-5. 
Appendix 1.

Informant:

1. Sex: Male $\square \quad$ Female $\square$

2. Age: $<20 \square ; \quad 20-29 \square ; 30-39 \square ; 40-49 \square ; \quad 50-60 \square ; \quad>60 \square$.

3. Family situation: Single $\square$; Married $\square$.

Academic level: None $\square$; Primary $\square$; Secondary $\square$; University $\square$.

Residential Headquarters:

Do you know any plants in the region that are in high demand or exported to a national or international market?

7. Are you a plant user aromatic and medicinal? Yes $\square$ No $\square$

8. When you want to use plants (plant-based) you orient yourself by: Yourself $\square$; books $\square$; herbalists $\square$; training $\square$; others' experiences $\square$; audiovisual programs $\square$; others $\square$.

10. Which plants do you use most often:

Legend:

fl: flowers / le: leaves / fr: fruits / st: stem / se: seed / ro: root /ba: bark / wp: whole plant.

${ }^{*}$ surround and check the good proposal

\begin{tabular}{|c|c|c|c|c|c|c|c|c|c|c|}
\hline \multirow{2}{*}{$\begin{array}{l}\text { Latin } \\
\text { name }\end{array}$} & \multirow{2}{*}{ Use } & \multirow{2}{*}{ If food } & \multirow{2}{*}{ If coloring } & \multicolumn{4}{|c|}{ Part used } & \multirow{2}{*}{$\begin{array}{l}\text { Side } \\
\text { effects }\end{array}$} & \multirow{2}{*}{$\begin{array}{c}\text { Special } \\
\text { properties }\end{array}$} & \multirow{2}{*}{ procurement } \\
\hline & & & & Taste & Color & Aroma & Preservation & & & \\
\hline & $\begin{array}{l}\text { Food } \quad \square \\
\text { Therapeutic } \square \\
\text { Cosmetics } \square \\
\text { Other } \quad \square\end{array}$ & $\begin{array}{l}\text { Taste }(\ldots \ldots . . .) \square \\
\text { Color }(\ldots \ldots . . .) \square \\
\text { Aroma } \quad \square \\
\text { Preservation } \square \\
\text { Other } \quad \square\end{array}$ & $\begin{array}{l}\text { Food } \\
\text { Hair } \\
\text { Skin } \\
\text { Fabric and thread } \\
\text { Basket } \\
\text { Pottery } \\
\text { Wall } \\
\text { Board } \\
\text { Other }\end{array}$ & $\begin{array}{l}\mathrm{fl} \\
\mathrm{le} \\
\mathrm{fr} \\
\mathrm{st} \\
\text { se } \\
\text { ro } \\
\text { ba } \\
\text { wp }\end{array}$ & $\begin{array}{l}\mathrm{fl} \\
\mathrm{le} \\
\mathrm{fr} \\
\mathrm{st} \\
\mathrm{se} \\
\mathrm{ro} \\
\mathrm{ba} \\
\mathrm{wp}\end{array}$ & $\begin{array}{l}\mathrm{fl} \\
\mathrm{le} \\
\mathrm{fr} \\
\mathrm{st} \\
\mathrm{se} \\
\mathrm{ro} \\
\mathrm{ba} \\
\mathrm{wp}\end{array}$ & $\begin{array}{l}\mathrm{fl} \\
\mathrm{le} \\
\mathrm{fr} \\
\text { st } \\
\text { se } \\
\text { ro } \\
\text { ba } \\
\text { wp }\end{array}$ & & & $\begin{array}{l}\text { - Local: Yes } \square \text { No } \square \\
\text { - If yes: Abundant Yes } \square \text { No } \square \\
\text { - If not origin (..........) } \\
\text {-Wild } \square \text { Cultivated } \square \\
\text { - Very locally requested } \\
\text { Yes } \square \text { No } \square \\
\text {-Exported: Yes } \square \text { No } \square\end{array}$ \\
\hline
\end{tabular}


Appendix 2. Summary table of aromatic and medicinal plants listed as sources of food additives in the survey with their number of indications

\begin{tabular}{|c|c|c|c|c|c|c|}
\hline$N^{\circ}$ & Plant species & Family & Dye & Preservative & Aroma & $\begin{array}{c}\text { Relative frequency of } \\
\text { citation (RFC ; \%) }\end{array}$ \\
\hline 1 & Punica granatum $\mathrm{L}$. & Punicaceae & $\mathrm{X}$ & & & 0,11 \\
\hline 2 & Curcuma longa $\mathrm{L}$. & Zingiberaceae & $\mathrm{X}$ & $\mathrm{X}$ & & 0,09 \\
\hline 3 & Matricaria chamomilla L. & Asteraceae & $\mathrm{X}$ & & $\mathrm{X}$ & 0,09 \\
\hline 4 & Crocus sativus L. & Iridaceae & $\mathrm{X}$ & & $\mathrm{X}$ & 0,08 \\
\hline 5 & Capsicum annuum L. & Solanaceae & $\mathrm{X}$ & & & 0,05 \\
\hline 6 & Carthamus tinctorius L. & Asteraceae & $\mathrm{X}$ & & & 0,05 \\
\hline 7 & Rubia peregrina $\mathrm{L}$. & Rubiaceae & $\mathrm{X}$ & & & 0,05 \\
\hline 8 & Rosmarinus Officinalis L. & Lamiaceae & $\mathrm{X}$ & $\mathrm{X}$ & $\mathrm{X}$ & 0,04 \\
\hline 9 & Ammodaucus leucotrichus Coss. & Apiaceae & $\mathrm{X}$ & & & 0,04 \\
\hline 10 & Hibiscus sabdariffa L. & Malvaceae & $\mathrm{X}$ & & $\mathrm{X}$ & 0,04 \\
\hline 11 & Thymus zygis subsp. gracilis (Boiss.) R. Morales & Lamiaceae & $\mathrm{X}$ & $\mathrm{X}$ & $\mathrm{X}$ & 0,03 \\
\hline 12 & Thymus vulgaris $\mathrm{L}$. & Lamiaceae & $\mathrm{X}$ & $\mathrm{X}$ & $\mathrm{X}$ & 0,03 \\
\hline 13 & Thymus satureioides Coss. & Lamiaceae & $\mathrm{X}$ & $\mathrm{X}$ & $\mathrm{X}$ & 0,03 \\
\hline 14 & Papaver rhoeas L. & Papaveraceae & $\mathrm{X}$ & & & 0,03 \\
\hline 15 & Beta vulgaris L. & Amaranthaceae & $\mathrm{X}$ & & & 0,02 \\
\hline 16 & Trigonella foenum-graecum $\mathrm{L}$. & Fabaceae & $\mathrm{X}$ & $\mathrm{X}$ & & 0,02 \\
\hline 17 & Quercus rotundifolia Lam. & Fagaceae & $\mathrm{X}$ & & & 0,02 \\
\hline 18 & Juglans regia L. & Juglandaceae & $\mathrm{X}$ & & & 0,02 \\
\hline 19 & Daphne gnidium L. & Thymelaeaceae & $\mathrm{X}$ & & & 0,02 \\
\hline 20 & Alpinia officinarum Hance & Zingiberaceae & $\mathrm{X}$ & & & 0,02 \\
\hline 21 & Pistacia lentiscus L. & Anacardiaceae & $\mathrm{X}$ & $\mathrm{X}$ & & 0,02 \\
\hline 22 & Myristica fragrans Houtt. & Myristicaceae & $\mathrm{X}$ & & & 0,02 \\
\hline 23 & Avena sterilis L. & Poaceae & $\mathrm{X}$ & $\mathrm{X}$ & & 0,02 \\
\hline 24 & Ziziphus lotus (L.) Lam. & Rhamnaceae & $\mathrm{X}$ & & & 0,02 \\
\hline 25 & Rubus ulmifolius Schott & Rosaceae & $\mathrm{X}$ & & & 0,02 \\
\hline 26 & Populus nigra L. & Salicaceae & $x$ & & & 0,02 \\
\hline 27 & Artemisia herba-alba Asso & Asteraceae & $\mathrm{X}$ & $\mathrm{X}$ & $\mathrm{X}$ & 0,02 \\
\hline 28 & Calendula officinalis L. & Asteraceae & $\mathrm{X}$ & & & 0,02 \\
\hline 29 & Herniaria hirsuta L. & Asteraceae & $x$ & & & 0,02 \\
\hline 30 & Lavandula dentata $\mathrm{L}$. & Asteraceae & $x$ & & $\mathrm{X}$ & 0,02 \\
\hline 31 & Salvia lavandulifolia Vahl & Asteraceae & $\mathrm{X}$ & $\mathrm{X}$ & $\mathrm{X}$ & 0,02 \\
\hline 32 & Isatis tinctoria $\mathrm{L}$. & Brassicaceae & $\mathrm{X}$ & & & 0,02 \\
\hline 33 & Cistus ladanifer $\mathrm{L}$. & Cistaceae & $\mathrm{X}$ & & & 0,02 \\
\hline 34 & Origanum compactum Benth. & Lamiaceae & $\mathrm{X}$ & $\mathrm{X}$ & $\mathrm{X}$ & 0,02 \\
\hline 35 & Origanum elongatum (Bonnet) Emb. \& Maire & Lamiaceae & $\mathrm{X}$ & $\mathrm{X}$ & $\mathrm{X}$ & 0,02 \\
\hline 36 & Laurus nobilis L. & Lauraceae & & $\mathrm{X}$ & $\mathrm{X}$ & 0,02 \\
\hline 37 & Lawsonia inermis L. & Lythraceae & $\mathrm{X}$ & & & 0,02 \\
\hline 38 & Eucalyptus globulus Labill. & Myrtaceae & & $\mathrm{X}$ & & 0,02 \\
\hline
\end{tabular}




\begin{tabular}{|c|c|c|c|c|c|c|}
\hline 39 & Myrtus communis L. & Myrtaceae & & $\bar{X}$ & & 0,02 \\
\hline 40 & Rosa canina L. & Rosaceae & & $\mathrm{X}$ & $\mathrm{X}$ & 0,02 \\
\hline 41 & Ruta montana L. & Rutaceae & & $\mathrm{X}$ & $\mathrm{X}$ & 0,02 \\
\hline 42 & Petroselinum sativum Hoffm. & Apiaceae & $\mathrm{X}$ & & $\mathrm{X}$ & 0,01 \\
\hline 43 & Coriandrum sativum $\mathrm{L}$. & Apiaceae & $\mathrm{X}$ & & $\mathrm{X}$ & 0,01 \\
\hline 44 & Foeniculum vulgare Mill. & Apiaceae & $\bar{X}$ & $x$ & $\mathrm{X}$ & 0,01 \\
\hline 45 & Urtica dioica $\mathrm{L}$. & Asteraceae & $\mathrm{X}$ & & $\mathrm{X}$ & 0,01 \\
\hline 46 & Helianthus Annuus L. & Asteraceae & & $\mathrm{X}$ & & 0,01 \\
\hline 47 & Anacyclus pyrethrum (L.) Lag. & Asteraceae & $\mathrm{X}$ & & & 0,01 \\
\hline 48 & Opuntia ficus-indica (L.) Mill. & Cactaceae & $\bar{X}$ & & & 0,01 \\
\hline 49 & Cupressus sempervirens L. & Cupressaceae & & $\mathrm{X}$ & & 0,01 \\
\hline 50 & Juniperus Communis L. & Cupressaceae & & $\mathrm{X}$ & & 0,01 \\
\hline 51 & Juniperus oxycedrus L. & Cupressaceae & & $\mathrm{X}$ & & 0,01 \\
\hline 52 & Ajuga iva (L.) Schreb. & Lamiaceae & $\mathrm{X}$ & & & 0,01 \\
\hline 53 & Satureja montana L. & Lamiaceae & & $X$ & $X$ & 0,01 \\
\hline 54 & Mentha $\times$ piperita L. & Lamiaceae & & $\mathrm{X}$ & $\mathrm{X}$ & 0,01 \\
\hline 55 & Ocimum basilicum $\mathrm{L}$. & Lamiaceae & & $\mathrm{X}$ & $\mathrm{X}$ & 0,01 \\
\hline 56 & Melissa officinalis L. & Lamiaceae & & $\mathrm{X}$ & $\mathrm{X}$ & 0,01 \\
\hline 57 & Mentha spicata L. & Lamiaceae & & & $\mathrm{X}$ & 0,01 \\
\hline 58 & Allium cepa $\mathrm{L}$. & Liliaceae & $\mathrm{X}$ & $\mathrm{X}$ & & 0,01 \\
\hline 59 & Syzygium aromaticum (L.) Merr. \& L.M.Perry & Myrtaceae & $\mathrm{X}$ & $\mathrm{X}$ & & 0,01 \\
\hline 60 & Cymbopogon citratus (DC.) Stapf & Poaceae & & $\mathrm{X}$ & $\mathrm{X}$ & 0,01 \\
\hline 61 & Pimpinella anisum $\mathrm{L}$. & $\overline{\text { Apiaceae }}$ & $X$ & $\mathrm{X}$ & $\mathrm{X}$ & 0,01 \\
\hline 62 & Cuminum cyminum L. & Apiaceae & & & $\mathrm{X}$ & 0,01 \\
\hline 63 & Carduus tenuiflorus Curtis & Asteraceae & $\mathrm{X}$ & & & 0,01 \\
\hline 64 & Capparis spinosa L. & Capparaceae & & & $\mathrm{X}$ & 0,01 \\
\hline 65 & Glycyrrhiza glabra L. & Fabaceae & $\mathrm{X}$ & & & 0,01 \\
\hline 66 & Ceratonia siliqua L. & Fabaceae & $\mathrm{X}$ & & & 0,01 \\
\hline 67 & Illicium verum Hook. f. & Illiciaceae & $\mathrm{X}$ & & & 0,01 \\
\hline 68 & Mentha pulegium L. & Lamiaceae & & & $\mathrm{X}$ & 0,01 \\
\hline 69 & Mentha suaveolens Ehrh. & Lamiaceae & & & $\mathrm{X}$ & 0,01 \\
\hline 70 & Cinnamomum cassia Siebold & Lauraceae & $\mathrm{X}$ & $\mathrm{X}$ & & 0,01 \\
\hline 71 & Allium sativum $\mathrm{L}$. & Liliaceae & $\mathrm{X}$ & $\mathrm{X}$ & & 0,01 \\
\hline 72 & Malva sylvestris L. & Malvaceae & & & $\mathrm{X}$ & 0,01 \\
\hline 73 & Morus alba L. & Moraceae & $\mathrm{X}$ & & & 0,01 \\
\hline 74 & Jasminum grandiflorum $\mathrm{L}$. & Oleaceae & & & $\mathrm{X}$ & 0,01 \\
\hline 75 & Ranunculus bullatus L. & Ranunculaceae & $\mathrm{X}$ & & & 0,01 \\
\hline 76 & Prunus dulcis (Mill.) D.A.Webb & Rosaceae & & & $\mathrm{X}$ & 0,01 \\
\hline 77 & Citrus $\times$ aurantium $\mathrm{L}$ & $\overline{\text { Rutaceae }}$ & $X$ & & $\mathrm{X}$ & 0,01 \\
\hline 78 & Citrus $\times$ limon (L.) Osbeck & Rutaceae & $\mathrm{X}$ & & $\mathrm{X}$ & 0,01 \\
\hline 79 & Verbena officinalis $\mathrm{L}$. & Verbenaceae & & & $\mathrm{X}$ & 0,01 \\
\hline
\end{tabular}


Appendix 3. Distribution of botanical families surveyed by frequency and percentage of citations

\begin{tabular}{lcc}
\hline \multicolumn{1}{c}{ Families } & Frequency of citation & $\begin{array}{c}\text { Percentage of citation } \\
(\%)\end{array}$ \\
\hline Asteraceae & 48 & 16,55 \\
\hline Lamiaceae & 44 & 15,17 \\
\hline Punicaceae & 21 & 7,24 \\
\hline Zingiberaceae & 21 & 7,24 \\
\hline Apiaceae & 15 & 5,17 \\
\hline Iridaceae & 15 & 5,17 \\
\hline Fabaceae & 10 & 3,45 \\
\hline Solanaceae & 10 & 3,45 \\
\hline Rubiaceae & 9 & 3,10 \\
\hline Malvaceae & 8 & 2,76 \\
\hline Myrtaceae & 8 & 2,76 \\
\hline Rosaceae & 8 & 2,76 \\
\hline Cupressaceae & 6 & 2,07 \\
\hline Poaceae & 6 & 2,07 \\
\hline Papaveraceae & 5 & 1,72 \\
\hline Rutaceae & 5 & 1,72 \\
\hline Amaranthaceae & 4 & 1,38 \\
\hline Anacardiaceae & 4 & 1,38 \\
\hline Juglandaceae & 4 & 1,38 \\
\hline Lauraceae & 4 & 1,38 \\
\hline Myristicaceae & 4 & 1,38 \\
\hline Rhamnaceae & 4 & 1,38 \\
\hline Thymelaeaceae & 4 & 1,38 \\
\hline Brassicaceae & 3 & 1,03 \\
\hline Cistaceae & 3 & 1,03 \\
\hline Liliaceae & 3 & 1,03 \\
\hline Lythraceae & 3 & 1,03 \\
\hline Salicaceae & 3 & 1,03 \\
\hline Cactaceae & 2 & 0,69 \\
\hline Capparaceae & 1 & 0,34 \\
\hline Illiciaceae & 1 & 0,34 \\
\hline Moraceae & 1 & 0,34 \\
\hline Oleaceae & 1 & 0,34 \\
\hline Ranunculaceae & 1 & 0,34 \\
\hline Verbenaceae & 1 & 0,34 \\
\hline Total (35 families) & $\mathbf{1 0 0} \%$ \\
\hline & 290 indications & \\
\hline & & \\
\hline & 4 & \\
\hline
\end{tabular}


Appendix 4. Monograph of the most represented plant families in the study areas

Key : EN, English Name FN, French Name CN, Common Name PU, Part used LTA, Local traditional application T, Toxicity.

\section{AMARANTHACEAE}

Beta vulgaris $\mathrm{L}$.

EN: Beetroot

FN: Betterave commune

CN: Barba

- PU: Bulbs

- LTA: Dye; emollient laxative.

\section{ANACARDIACEAE}

\section{Pistacia lentiscus L.}

EN: Lentisk

FN: Pistachier lentisque

CN: Drou

- PU: Leaves, bark

- LTA: Dye, preservative, sore belly; ailments of the intestine; antidiarrheal; antidiabetic, emmenagogues; diuretics; analgesics; antipyretic, astringent.

\section{APIACEAE}

Ammodaucus leucotrichus Coss.

- EN: Cumin hairy

FN: Cumin velu

CN: Kammûnsofi, Cumin laineux

PU: Fruits

- LTA: Dye; vomiting, nausea, dysentery; diuretic and stimulating

\section{Petroselinum sativum Hoffm.}

- EN: Parsley

FN: Persil

CN: Maâdnous

- PU: aerial part, stem and seed

LTA: Dye, aromatic, antidiabetic, kidney stones, urolithiasis, hot, attenuating, appetizer, detergent, diuretic, expectorant, hepatic, emmenagogue, tonic, general stimulant, anti-anemia agent, stomachic, depurative, vermifuge, rheumatism.

- T: Possible inflammation of the nerves and also a risk of miscarriage during pregnancy.

\section{Cuminum cyminum $\mathrm{L}$}

EN: Cumin
FN: Cumin
CN: Kamoun
PU: Seeds 
- LTA: Aromatic; digestive problems; urinary tract inflammation; carminative; antidiarrheal; antispasmodic, sudorific, galactogenic, stimulant, anthelmintic, diuretic and against mumps.
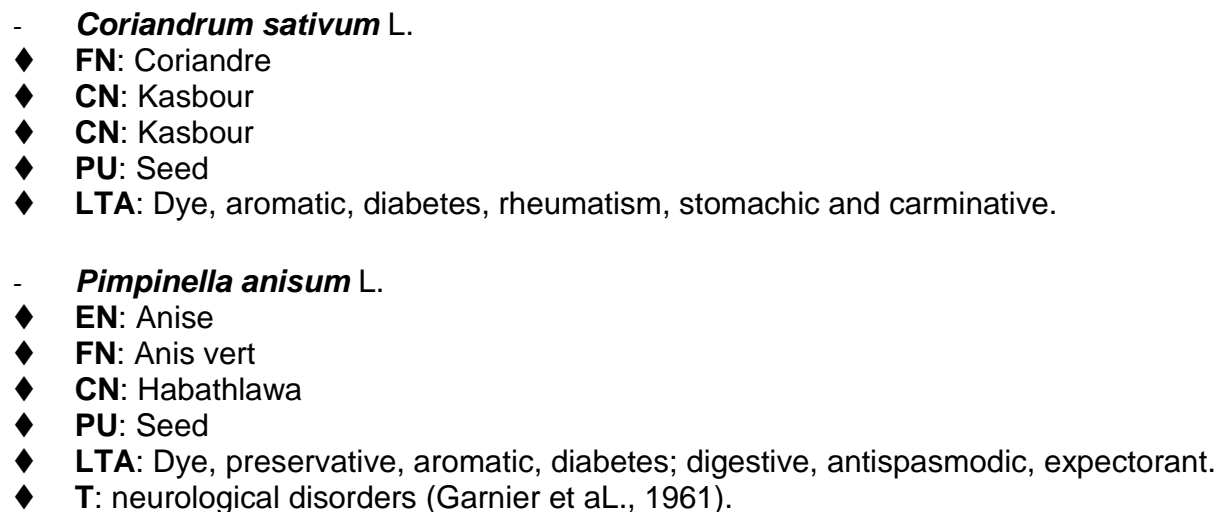

\section{Foeniculum vulgare MilL.}

\section{EN: wild fennel}

FN: Fenouilsauvage

CN: Nafaâ El-beldi, Bessbass

PU: seed, Côtes

LTA: Preservative, Dye, aromatic, antidiabetic, anti-inflammatory, digestive diseases, stimulates lactation, antiparasitic.

- T: Anethole, the principle of the essential oil of fennel is used by Moroccan Jews to flavor alcohoL. Evil dosed once it caused a few accidents (stupor, hallucinations, convulsions) in people already ailing due to alcoholism (Bellakhdar 1997).

\section{ASTERACEAE}

Anacyclus pyrethrum (L.) Lag.

EN: African Pyrethrum

FN: Pyrèthre d'Afrique

CN: Aerq Chleuh/ Tiguentest

PU: whole plant

LTA: Dye; against cysts of the genital tract; diabetes;

- T: Skin irritation of the mucous membranes; nausea; fainting; respiratory disorders; gastrointestinal irritation, gastro-enteritis, colic, diarrhea; convulsions and headaches (Hmammouchi, 1999). Fumes, headache, tinnitus, and even loss of consciousness (Anonymous, 2009).

\footnotetext{
Artemisia herba-alba Asso

EN: White Wormwood

FN: Armoise blanche

CN: Chih, Izri

- PU: whole plant
} 
- LTA: Dye, preservative, aromatic, gastrointestinal disorders, diabetes, ulcers, fever, intestinal parasites, rheumatism, constipation, heart disease, menstrual pain, cough, liver diseases, skin diseases, kidney disease, cancer, hair loss and anemia.

- T: In high doses, wormwood is neurotoxic abortion, hemorrhage (Pierre \& Read, 1992).

\title{
Calendula officinalis $\mathrm{L}$.
}

EN: Marigold

FN: Souci officinal

CN: Jemra

PU: flowers

- LTA: Dye; Anti-inflammatory, hypotensive, spasmolytic, immunostimulant and cholesterol-lowering, anti-edematous, anti-venom, antibacterial, antiviral, antifungal and anticancer healing.

\author{
Carduus tenuiflorus Curtis \\ EN: thistle \\ FN: chardon à capitulesgrêles \\ CN: Chouka hmar \\ PU: Flower heads \\ - LTA: Dye; hepatoprotective, anti-inflammatory, anti-spasmodic, hypotensive. \\ - T: severe toxicity has been rarely reported.
}

\section{Carthamus tinctorius L.}

- EN: Safflower

FN: Carthame

CN: Quertum

PU: Stigma, Seed

LTA: Dye; diabetes; good for the lungs and stomach and relieves joint pain.

- T: Mildnephrotoxicity (Liu et aL., 2004)

\section{Lavandula dentata $\mathrm{L}$.}

- EN: Lavender

FN: Lavande à feuillesdentées

CN: El-khzama

- PU: The stems with leaves, inflorescence and the aerial part.

- LTA: Dye, aromatic, diabetes; Tonic, diuretic, vulnerary, antiseptic; To treat gastroduodenal disorders, kidney stones, dizziness and heavy periods, it uses the toothed lavender powder or infusion. The plant decoction is recommended in case of gastric acidity and liver diseases. Externally, chopped fresh plant applied on wounds, injuries, body lice and head, to disinfect. The oil friction is applied to the painful joint against rheumatism.

\section{Herniaria hirsuta L.}

EN: hairy rupturewort

FN: Herniaire

- CN: Hrraslehjar

PU: whole plant

LTA: Dye; Against the pain of the urinary tract and the cold weather; kidney stones; wounds and ulcers 


\section{Helianthus annuus $\mathrm{L}$.}

- EN: Sunflower

FN: Tournesol

CN: Nouarat chamess

- PU: Leaves, Roots Seeds

- LTA: Preservative; antifungal; antibacterial; antioxidant; antidiabetic;

\section{Matricaria chamomilla L.}

EN: Chamomile

FN:Camomille vraie Camomille sauvage ;

CN: Babounje

PU: capitulates

- LTA: Dye, aromatic, diabetes; anti-inflammatory, antispasmodic, vulnerary, anti-allergic.

\section{Salvia lavandulifolia Vahl}

- EN: Sage

FN: Sauge

FN: Sauge

- PU: Leaves

- LTA: Dye, preservative, aromatic, diabetes; Preservative; Emmenagogue, cholagogue, diuretic, anti-dyspeptic, antiseptic, anti-inflammatory, stimulating, choleretic, antispasmodic, antiperspirant, carminative, choleretic, stomachic, astringent, warming.

- T: The essential oil, in particular, can cause epileptiform convulsions (Bruneton 1996).

\section{Urtica dioica $\mathrm{L}$.}

EN: Nettle

CN: L-hurrîga

- PU: whole plant except the root

LTA: Dye, aromatic, anemia, rheumatism and hair loss, thyroid problems, adrenal gland, diuretic, obesity, circulatory problems, liver disease, cold, hyperglycemia, circulatory problems, prostate, cholesterol, skin rashes, hair care / anti-diabetic, anti-inflammatory, anti-inflammatory, coagulating.

\section{BRASSICACEAE}

Isatis tinctoria L.

EN: Woad

FN: Pastel des teinturiers

CN: Fajir

PU: Leaf

- LTA: Dye; treatment edema, tumors and wounds. 


\section{CACTACEAE}

Opuntia ficus-indica (L.) MilL.

EN: Prickly pear

FN: Figuier d'Inde,Figuier de barbarie

- CN: Aknarî, Handiya, Karmôs-ennsârâ

- PU: Snowshoeing, flower and root

LTA: Dye; antidiabetics; Kidney stones; Anti-inflammatory; against diarrhea and hemorrhoids

- T: Non-toxic, but ingestion of a large number of fruit causes persistent and sometimes dangerous constipation (Kahouadji 1995).

\section{CAPPARACEAE}

\section{Capparis spinosa L.}

EN: Caper bush

EN: Caper bust

FN: Câprier
CN: Kabâr, taylult

- PU: The aerial part, the fruit and root

LTA: Aromatic; diabetes; against weak heart, against disease spleen, swelling of the body and disturbances of the urinary system, antirheumatic, back against disease and maturation abscesses.

\section{CISTACEAE}

Cistus ladanifer L.

EN: Gum rockrose

FN: Cisteladanifère

CN: Touzalt

PU: Leaf

LTA: dye; diabetes; antidiarrheal, stomach pain; injuries; asthma.

\section{CUPRESSACEAE}

-Juniperus communis L.

EN: Common juniper

FN: Genévriercommun

CN: Elarâr - Amzi

PU: leaves

LTA: Preservative; diabetes; In diuretic, digestive and stomachic.

\section{Juniperus oxycedrus $\mathrm{L}$. \\ - EN: Cade juniper \\ - FN: Genévrieroxycédre \\ - CN: El arâar - el gadi \\ - PU: Leaves}


- LTA: Preservative; Haircare, and neurological, diabetes.

Cupressus sempervirens $\mathrm{L}$.

- EN: Mediterranean cypress

- FN: Cyprèscommun

- CN: Srou

- PU: leaves and stems

- LTA: Preservative; diabetes; vasocon-strictor properties.

\title{
FABACEAE
}

Ceratonia siliqua $\mathrm{L}$.

- EN: Carob tree

- FN: Caroubier

- CN: L-kharrôb, Tikkida

- PU: fruit (pod) and bark

- LTA: Dye; antidiarrheal; diabetes; Stomachic, digestive diseases, respiratory diseases.

\section{Trigonella foenum-graecum L.}

EN: Fenugreek

FN: Fenugrec

- CN: L-halba

- PU: Seed

- LTA: Preservative, Dye; tonic, hypoglycemic, hypocholesterolemic, detoxifying, anti-asthmatic, detoxifying, anthelmintic, antihypertensive, aphrodisiac, gastroduodenal disorders, coughs and constipation.

\section{- Glycyrrhiza glabra L.}

EN: licorice;

FN: Réglisse

CN: Arquîs

PU: Root

- LTA: Dye; diuretic, refreshing, digestive, anti-inflammatory, depurative, tonic, expectorant, antispasmodic, antihistaminic, softening, chest.

- T: it is hypertension, edema accompanied by various disorders and resistant to treatment, followed by paralytic phenomena and heart rhythm disorders (Hmamouchi, 1999).

\author{
Quercus rotundifolia Lam. \\ - EN: oak \\ FN: chêne vert \\ CN: Korrich \\ PU: Bark, Fruit, leaf \\ - LTA: Dye; gastric pains; antidiabetic, tonic and antidiarrheaL.
}

- T: Fruits absorbed in large quantities cause delay digestion with nausea, abdominal pain and headache. 


\section{ILLICIACEAE}

Illicium verum Hook. $f$.

EN: Star Anise

FN: Badianier de Chine

- CN: Badiana

- PU: fruit

- LTA: Dye; diabetes, ENT disorders, digestive disorders, antiviral, antimicrobiaL.

\section{IRIDACEAE}

Crocus sativus $\mathrm{L}$.

EN: saffron

- FN: Vraisafran

- CN: Za'franelhor

- PU: stigma flowers

- LTA: Dye; stones; Antidepressant, analgesic, kidney stones; cancer.

\section{JUGLANDACEAE}

\section{Juglans regia $\mathrm{L}$}

- EN: Walnut

- FN: Noyer

- CN: L-guergua'a

- PU: The leaf and bark

- LTA: Dye; antimicrobial, antidiabetic.

\section{LAMIACEAE}

Ajuga iva (L.) Schreb.

EN: Bugle, Ivette

FN: Bugle, Ivette

CN: Chendgûra, Tûftolba

- PU: The stems with leaves and the aerial part

- LTA: Dye, detoxing, warming, antidiabetic, anthelmintic, hypoglycemic, astringent, antispasmodic, exciting, antidiarrheal, appetizer, anti-inflammatory, sedative, antipyretic, tonic, antiseptic, eupeptic, vulnerary, hypotensive, anti-cancer and ear ailments.

- T: Ajuga iva (from Morocco) is not toxic, but seems endowed with a sedative power (Bennaghmouch\& aL., 2001).

\section{Ocimum basilicum L.}

EN: Basil

FN: Basilic

- CN: Lahbaq

- PU: The stems with leaves 
LTA: Preservative, aromatic; diabetes; Urogenital; Antispasmodic, stomachic, galactagogue, pectoral, sedative, sternutatory; anti-inflammatory.

T:The essential oil of the plant is dermo-caustic (Hmamouchi, 1999).

\section{Origanum elongatum (Bonnet) Emb. \& Maire}

EN: oregano

FN: origan

CN: Zaâtar

PU: The flowering tops and the stems with leaves

LTA: Preservative, dye, aromatic, antipyretic, expectorant, sedative, antispasmodic, intestinal, digestive, antiseptic, hypotensive, bactericidal, diuretic, sedative, tonic.

- T: high dose, oregano is toxic and narcotic (Bainy 1993).

\section{Origanum compactum L.}

EN: oregano

FN: origan

CN: Azukenni, Za'tar

PU: The flowering tops and the stems with leaves

LTA: Preservative, dye, aromatic, stomachic, digestive, vulnerary, aphrodisiac, antispasmodic cough, expectorant, hypoglycemic, antiseptic, anti-inflammatory, tonic, appetite stimulant.

- T: high dose, oregano is toxic and narcotic (Bainy 1993).

\section{Melissa officinalis L.}

- EN: Melissa

FN: Melissa

CN: Tourenjan

PU: Leaves

- LTA: Preservative, aromatic; diabetes;digestive disease and cure for the intestines; herpes; antispasmodic.

\section{Mentha $\times$ piperita $\mathrm{L}$}

EN: Peppermint

FN: menthe poivrée

CN: naenaaeabdi

- PU: aerial part

- LTA: Preservative, aromatic; Stomachic, antispasmodic, relieve headaches, neuralgic, anti-inflammatory, eczema and biliary and pancreatic insufficiency.

\section{Mentha pulegium L.}

EN: Pennyroyal

FN: Menthe pouliot

CN: Fliyyo

PU: aerial part

LTA: Aromatic; diabetes; Antitussive, cholagogue, expectorant, carminative, digestive, antispasmodic, pulmonary antiseptic, refreshing, tonic, appetizer, stomachic, antitussive, choleretic.

- T: In high doses, pennyroyal is anAbortion plant and very neurotoxic (Franchomme\&Penoë 2001). Ditto for the essential oil (Hmamouchi, 1999). 


\section{Ethnobotany Research and Applications}

\section{Mentha spicata $L$}

EN: Spearmint

FN: Menthe enépi

CN: Naanaa

PU: Leaves

- LTA: Aromatic, hypotension, sedative, disinfectant, astringent, carminative, stomach, sedative, refreshing; stomachic

\section{Mentha suaveolens Ehrh.}

EN: Pineapple mint

FN: Menthe à feuilles rondes

CN: Marseta

PU: whole plant

- LTA: Aromatic; diabetes; Laxative, tonic, digestive, diuretic, carminative, stomachic, eupeptic, antispasmodic, antiseptic, analgesic, anti-haemorrhoidal, antirheumatic.

\section{Rosmarinus officinalis $\mathrm{L}$.}

EN: Rosemary

FN: Romarin

CN: Azir

- PU: leaves

- LTA: Dye, Preservative, aromatic; antidiabetic, kidney stones; drink, tonic, fortifying the heart, diuretic, choleretic, spasmolytic, antioxidant, hypoglycemic, vulnerary, stimulant, antispasmodic, antiseptic, antirheumatic, analgesic, emmenagogue, healing, hepato-protective, antifungal, antibacterial, anti-tumorigenic.

- T: the essential oil is neurotoxic saw the presence of camphor in its composition. The use of leaves, infusion, is not recommended for pregnant women (risk of abortion) (AGRA 1996). Chronic poisoning manifests as stomach bleeding, liver and albuminuria stéatomes (Hmamouchi, 1999).

\section{Satureja montana L.}

EN: savory

FN: sarriette

- CN: Zâaetra, Touwichant, Zoukeni

PU: whole plant

LTA: Preservative, aromatic; intestinal disorders, vomiting, heart disease, stomach ulcer and acute diseases, eczema, gargle against dental aches and sore throats;

- T: The essential oil is dermocaustic (Hmamouchi, 1999)

\section{Thymus satureioides Coss.}

EN: Thyme-savory Morocco, Thyme saturéoïde

- FN: Thym-sariette du Maroc, Thym saturéoïde

CN: Ziîtra

- PU: The sheet

- LTA: Preservative, dye, aromatic, antiseptic, diuretic, emmenagogue, tonic, antispasmodic, anthelmintic, carminative, anthelmintic, healing, antitussive, stimulant, expectorant, antipyretic, deodorant, repellent, eupeptic, sedative, vulnerary.

\section{Thymus vulgaris L.}

EN: Common thyme

- FN: Thymcultivé, Thymcommun 
CN: Azoukni

PU: leaf

- LTA: Preservative, dye, aromatic, antiseptic, diuretic, emmenagogue, tonic, antispasmodic, anthelmintic, carminative, anthelmintic, healing, antitussive, stimulant, expectorant, antipyretic, deodorant, repellent, eupeptic, sedative, vulnerary.

\section{Thymus zygis subsp. gracilis (Boiss.) R. Morales}

EN: wild thyme

- FN: thymsauvage

CN: Tazuknite, Ziitra

- PU: Leaf

LTA: Preservative, dye, aromatic, antiseptic, diuretic, emmenagogue, tonic, antispasmodic, anthelmintic, carminative, anthelmintic, healing, antitussive, stimulant, expectorant, antipyretic, deodorant, repellent, eupeptic, sedative, vulnerary.

\section{LAURACEAE}

Cinnamomum cassia Siebold

EN: Cinnamon

- FN: Cannelle

CN: L-Qarfa

- PU: Bark

LTA: Dye, preservative, gallstones, diabetes, cancer, orofacial disorders.

\section{- Laurus nobilis L.}

- EN: Laurel

- FN: Laurier noble

- CN: Assâsîdnamûssa, Rand

$\checkmark$ PU: leaf

- LTA: Aromatic, preservative, anti-diabetic; respiratory problems, nervous system diseases, dialysis, cough, hypertension, musculoskeletal and digestive problems, cardiovascular disease / hypoglycemic, tonics, carminative, genitourinary diseases

\section{AMARYLLIDACEAE}

Allium Cepa L.

EN: Onion

FN: Oignon

CN: L-bessla

PU: Bulb, pellure

- LTA: Dye, preservative, diabetes, kidney stones, antimicrobiaL.

\section{Allium sativum $\mathrm{L}$.}

- EN: Garlic

FN: Ail

- CN: Touma 
- PU: bulb

LTA: Dye, Preservative; kidney stones, antimicrobial, antiviraL.

\section{LYTHRACEAE}

Lawsonia inermis $\mathrm{L}$.

EN: Henna

FN: Henné

CN: L-henna

- PU: leaf

- LTA: Dye; antidiarrheal; nephrolithiasis; antidiabetic, antifungaL.

\section{MALVACEAE}

Hibiscus sabdariffa $\mathrm{L}$.

- EN: Roselle

- FN: Oseille de Guinée

- CN: Karkadi

- PU: flowers Calyxes

- LTA: Dye; aromatic, antidiabetic, antineoplastic, antipyretic, anti-inflammatory, antimicrobial, antiparasitic.

\section{Malva sylvestris $\mathrm{L}$}

EN: Mallow

FN: Grande mauve

CN: Khobbeyza

PU: Aerial parts

- LTA: Aromatic; Weight loss, gastrointestinal disorders, urinary system diseases, uterine pain, colds, stomach pain, skin and anti-inflammatory, emollient

\section{MORACEAE}

Morus alba $\mathrm{L}$.

- EN: Black mulberry

FN: Mûrier noir

CN: Etût

PU: leaf

- LTA: Dye; antidiabetic, antiviral, antimicrobiaL.

\section{MYRISTICACEAE}

Myristica fragrans Houtt.

- EN: Nutmeg / mace

FN: Muscadier

- CN: Lgouza, Bsibisa 
PU: The nuts and mace

LTA: Dye; lithiasis, aphrodisiac, anti-inflammatory, antimicrobiaL.

\section{MYRTACEAE}

Eucalyptus globulus LabilL.

EN: Eucalyptus

- FN: Eucalyptus

CN: Kalybtus

- PU: Leaves

- LTA: Preservative; diabetes; Colds and flu, leishmaniasis, respiratory and antitussive

Myrtus communis L.

EN: Myrtle

- FN: Myrtecommun

CN: Rihân

- PU: Leaves

- LTA: Preservative; diabetes;softening, fall, detangler, respiratory, cardiac and hepatic disease.

\section{Syzygium aromaticum (L.) Merr. \& L.M.Perry}

$\checkmark$ EN: Clove

FN: Giroflier

- CN: Qranfal

- PU: Flower buds

- LTA: Dye, Preservative; antimicrobial; anxiolytic; anti-inflammatory, antifungal, anesthetic, aromatic.

- T: Eugenol has strong dose may have genotoxic effects (Cortés-Rojas et al, 2014.).

\section{OLEACEAE}

Jasminum grandiflorum $\mathrm{L}$.

- EN: Jasmine

FN: Jasmin blanc

CN: Jawharedar

PU: Leaves

- LTA: Aromatic; neurological condition:

\section{PAPAVERACEAE}

\section{Papaver rhoeas $\mathrm{L}$}

EN: Poppy

FN: Coquelicot

CN: Belaamane

- PU: Petals

- LTA: Dye; aromatic, sedative, anxiolytic, anti-ulcerogenic. 
POACEAE

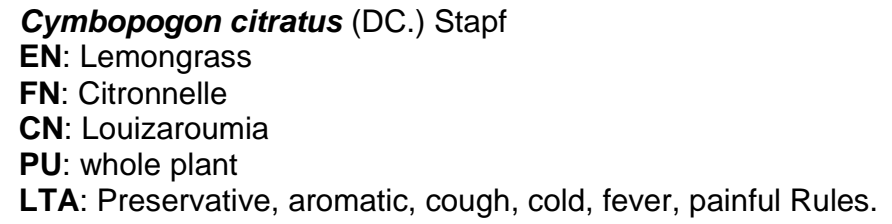

\section{Avena sterilis $\mathrm{L}$. \\ EN: Oats \\ FN: Avoinecultivée \\ CN: El-Khortal \\ PU: The seed}

- LTA: Dye, preservative, Antidiabetic, antioxidant, antithrombosis, anti-inflammatory, anticancer.

\section{PUNICACEAE}

Punica granatum $\mathrm{L}$.

EN: pomegranate tree

FN: Grenadier

CN: Rommân

PU: The bark of the fruit

LTA: Dye; antidiarrheal; stomachic; sntidiabétique, antioxidant.

- T: No toxicity to report, or indeterminate toxicity.

\section{RANUNCULACEAE}

Ranunculus bullatus $\mathrm{L}$.

- EN: Autumn buttercup

FN: Renoncule

- CN: wdenlhalouf

- PU: Root

- LTA: Dye; kidney stones, menstrual pain, upset stomach, inducing delivery, antidiarrheal, nephrolithiasis.

- T: Causes stomatitis, burns and ulceration (Bellakhdar 1997).

\section{RHAMNACEAE}

Ziziphus lotus (L.) Lam.

- EN: Jujube

- FN: Jujubier 
- CN: Ssedra, Nbeg. Azogar

PU: The leaves, fruit, roots and bark.

- LTA: Dye; kidney stones; stones; leucoma; antimicrobial; antidiabetic.

ROSACEAE

Rubus ulmifolius Schott

- EN: Elmleaf blackberry

- FN: Ronce à feuillesd'Orme

CN: Laâlîg

- PU: leaf

- LTA: Dye; antidiabeticantipyretic.

Rosa canina L.

EN: Rose

CN: Ward, Tighfert

PU: Leaves

LTA: Preservative; aromatic; Stomachic, erectile dysfunction, headache, fall; astringent, laxative, anti-diarrhea, anti-inflammatory and stimulating

Prunus dulcis (MilL.) D.A.Webb

EN: almond, sweet almond, bitter almond

FN : Amandier, amande douce, amande amère

CN: Lûz

PU: Fruit

LTA: Aromatic, antidiabetics; Incapacity; antiscléreux; eczema; antifungaL.

\section{RUBIACEAE}

Rubia peregrina $\mathrm{L}$.

EN: Madder

FN: garancevoyageuse

- CN: Fuwa

- PU: root and rhizome

LTA: Dye; jaundice; hepatoprotective effect; diuretic, appetizing, choleretic, emmenagogue and tonic

- T: Non-toxic at low doses (Kahouadji 1995).

\section{RUTACEAE}

Citrus aurantium $\mathrm{L}$.

- EN: Bitter Orange

FN: Bigaradier

- CN: Ranj, Zenboue

PU: Leaf, bark, fruit 
- LTA: Colrant, aromatisan, anti-diabetic, antioxidant, anti-cancer,

Citrus limon (L.) Osbeck

EN: lemon

FN: Bergamotier

CN: L-hamedbeldî

PU: Leaf, bark, fruit

- LTA: Dye, aromatic, antidiabetic, antihypertensive, anti-inflammatory, anti-fungal, respiratory ailments, heart ailments.

\section{Ruta montana L.}

EN: mountain rue

FN: Rue sauvage

CN: Fijel

PU: whole plant

LTA: Preservative, aromatic, digestive disorder, helminth infections, ulcers, rheumatism and difficult birth, stomach pain, infertility, analgesic, abortion, antispasmodic, anti-inflammatory (ophthalmic), emmenagogue, diuretic, sedative, sudorific, vermifuge, antimicrobial, diaphoretic;

- T: Leaves are irritant and blistering, properties due to the essential oil and in particular the methyl nonyl ketone is a rubefacient (EI Haji, 1995)

\section{SALICACEAE}

Populus nigra L.

- EN: black poplar

FN: Peuplier noir

CN: Baqs

PU: Leaf buds

LTA: Dye; antioxidant, anti-inflammatory, cardiovascular, hepatoprotective.

\section{SOLANACEAE}

Capsicum annuum $\mathrm{L}$.

EN: Pepper, Paprika

- FN: Poivron, Paprika

- CN: Felfla

PU: fruit

LTA: Dye; diabetic, post-herpetic neuralgia, musculoskeletal pains, diabetic neuropathy, osteoarthritis and rheumatoid arthritis.

\section{THYMELAEACEAE}

Daphne gnidium L.

- EN: Flax-leaved daphne

FN: Garou

- CN: Lezzâz

- PU: leaves, bark 
- LTA: Dye; antimicrobial; anti-inflammatory, anti-cancer.

T: All parts of the plant are irritating but fruits are most often involved. 1-2 fruits in children lead to accused symptoms and ingestion of 12 fruit is considered a potentially fatal dose in adults (Jouglard 1977)

\section{VERBENACEAE}

Verbena officinalis L.

EN: Verbena

FN: Verveine odorante

CN: Elouiza

PU: Leaves

LTA: Aromatic, diabetes; neurological condition; Against insomnia, and abdominal pain; hypotensive; Refreshing.

\section{ZINGIBERACEAE}

Curcuma longa L.

EN: Turmeric

FN: curcuma

CN: Iharqoum

PU: rhizome

- LTA: Dye, preservative, anti-inflammatory, anticoagulant, anticancer, hepatoprotective, antimicrobial,

\section{Alpinia officinarum Hance}

- EN: Lesser galangal

FN: Galanga officinal

CN: Khodenjal

PU: rhizome

- LTA: Dye; against colds, flu, cold, painful periods and as warming, aromatic, digestive, antiemetic, antiseptic. 